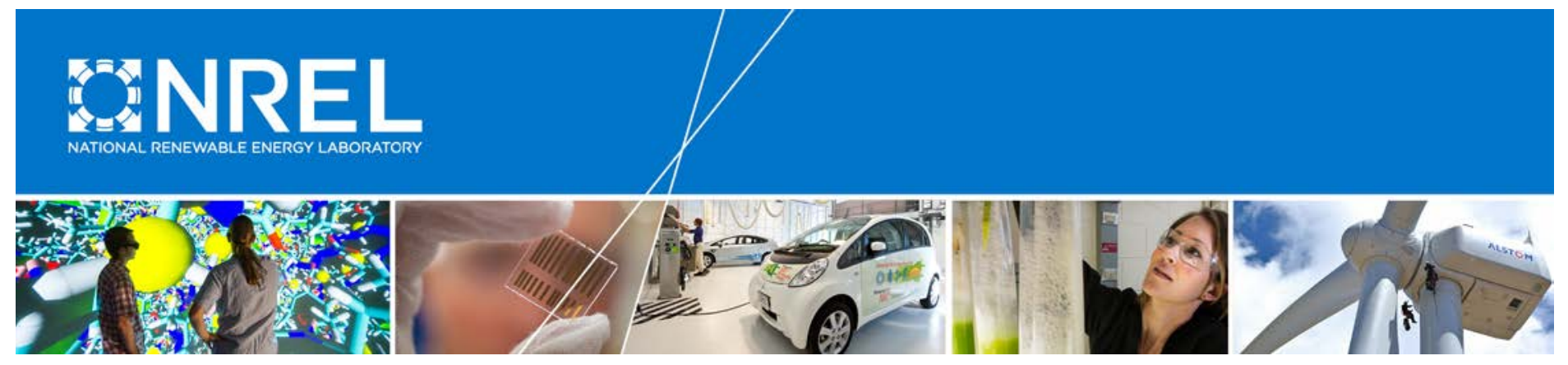

\title{
State Models to Incentivize and Streamline Small Hydropower Development
}

Taylor Curtis and Aaron Levine National Renewable Energy Laboratory

Kurt Johnson

Telluride Energy

NREL is a national laboratory of the U.S. Department of Energy Office of Energy Efficiency \& Renewable Energy Operated by the Alliance for Sustainable Energy, LLC

This report is available at no cost from the National Renewable Energy Laboratory (NREL) at www.nrel.gov/publications.

Technical Report

NREL/TP-6A20-70098

October 2017

Contract No. DE-AC36-08G028308 


\section{State Models to Incentivize and Streamline Small Hydropower Development}

Taylor Curtis and Aaron Levine National Renewable Energy Laboratory

Kurt Johnson

Telluride Energy
NREL is a national laboratory of the U.S. Department of Energy Office of Energy Efficiency \& Renewable Energy Operated by the Alliance for Sustainable Energy, LLC

This report is available at no cost from the National Renewable Energy Laboratory (NREL) at www.nrel.gov/publications.

\section{Technical Report}

NREL/TP-6A20-70098

October 2017

Contract No. DE-AC36-08G028308
National Renewable Energy Laboratory 15013 Denver West Parkway 303-275-3000 • www.nrel.gov 


\section{NOTICE}

This report was prepared as an account of work sponsored by an agency of the United States government. Neither the United States government nor any agency thereof, nor any of their employees, makes any warranty, express or implied, or assumes any legal liability or responsibility for the accuracy, completeness, or usefulness of any information, apparatus, product, or process disclosed, or represents that its use would not infringe privately owned rights. Reference herein to any specific commercial product, process, or service by trade name, trademark, manufacturer, or otherwise does not necessarily constitute or imply its endorsement, recommendation, or favoring by the United States government or any agency thereof. The views and opinions of authors expressed herein do not necessarily state or reflect those of the United States government or any agency thereof.

This report is available at no cost from the National Renewable Energy Laboratory (NREL) at www.nrel.gov/publications.

Available electronically at SciTech Connect http:/www.osti.gov/scitech

Available for a processing fee to U.S. Department of Energy and its contractors, in paper, from:

U.S. Department of Energy

Office of Scientific and Technical Information

P.O. Box 62

Oak Ridge, TN 37831-0062

OSTI http://www.osti.gov

Phone: 865.576 .8401

Fax: 865.576.5728

Email: reports@osti.gov

Available for sale to the public, in paper, from:

U.S. Department of Commerce

National Technical Information Service

5301 Shawnee Road

Alexandria, VA 22312

NTIS http://www.ntis.gov

Phone: 800.553 .6847 or 703.605 .6000

Fax: 703.605.6900

Email: orders@ntis.gov 


\section{Abstract}

In 2016, the hydropower fleet in the United States produced more than 6\% (approximately 265,829 gigawatt-hours [GWh]) of the total net electricity generation. The median-size hydroelectric facility in the United States is $1.6 \mathrm{MW}$ and $75 \%$ of total facilities have a nameplate capacity of 10 MW or less. Moreover, the U.S. Department of Energy's Hydropower Vision study modeled a scenario identifying approximately $49 \mathrm{GW}$ of deployable hydroelectric potential by 2050 . Much of the hydroelectric potential identified is at low-impact new stream-reaches, existing conduits, and non-powered dams with a median project size of $10 \mathrm{MW}$ or less. To optimize the potential and value of small hydropower development, state governments are crafting policies that provide financial assistance and expedite state and federal review processes for small hydroelectric projects. This report analyzes state-led initiatives and programs that incentivize and streamline small hydroelectric development. 


\section{Acknowledgments}

The authors gratefully acknowledge the EERE Water Power Technologies Office for its funding support. We also thank the following reviewers for their time and expertise: Corey Vezina and Tim Welch, U.S. Department of Energy, and Elise DeGeorge, Emily Newes, Dave Mooney, Laura Shields, and Kathryn Ruckman (editor), National Renewable Energy Laboratory. 


\section{Executive Summary}

This report analyzes state programs that incentivize small hydroelectric project development. Most U.S. hydropower plants are small. In 2016, the hydropower fleet in the United States produced more than $6 \%$ (approximately 265,829 gigawatt-hours [GWh]) of the total net electricity generation. The median-size hydroelectric facility in the United States is $1.6 \mathrm{MW}$, and $75 \%$ of total facilities have a nameplate capacity of $10 \mathrm{MW}$ or less. Moreover, the U.S. Department of Energy's Hydropower Vision study modeled a scenario identifying approximately $49 \mathrm{GW}$ of deployable hydroelectric potential by 2050 . Much of the hydroelectric potential identified is at low-impact new stream reaches, existing conduits, and non-powered dams with a median project size of $10 \mathrm{MW}$ or less. To optimize the potential and value of small hydropower development, state governments are crafting policies that provide financial assistance and expedite state and federal review processes. Financial incentives alone may not be sufficient to spur new small hydropower development. Regulatory streamlining efforts and permitting assistance alone may also not be sufficient. However, a combination of streamlining efforts and financial incentives may provide a path to success for encouraging new small hydropower development. 


\section{Table of Contents}

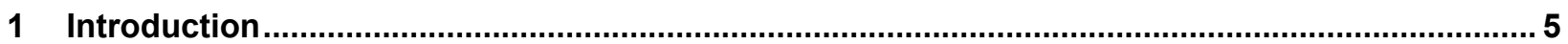

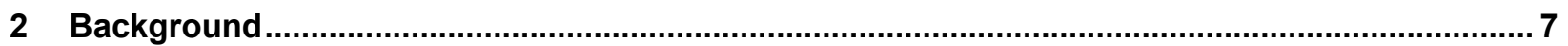

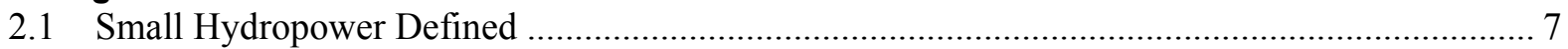

2.2 Federal and State Legislative Efforts Generally Supporting Small Hydropower Development ... 7

2.3 Current Market Conditions and Trends ............................................................................. 9

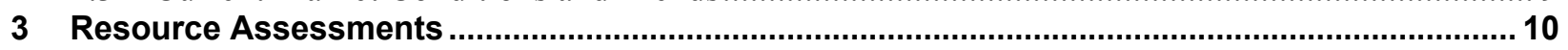

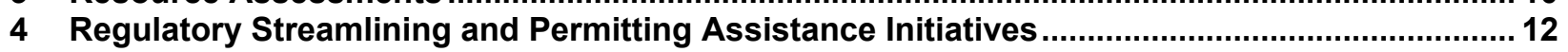

4.1 State-Agency-Implemented and Operated Program Models..................................................... 12

4.2 Independent, Nonprofit Implemented and Operated Program Models ..................................... 19

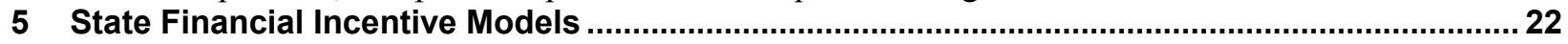

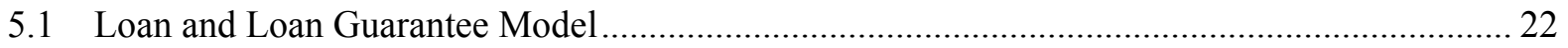

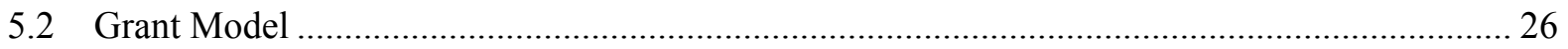

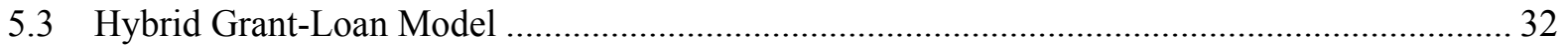

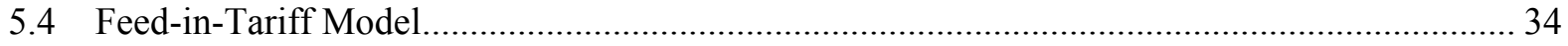

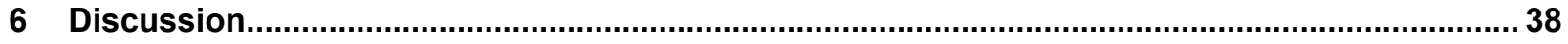

6.1 General Advantages and Challenges of Regulatory Streamlining and Permitting Assistance

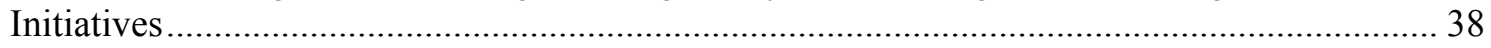

6.2 General Advantages and Challenges of Loan and Loan Guarantee Models ............................. 38

6.3 General Advantages and Challenges of Grant Models............................................................... 39

6.4 General Advantages and Challenges of Hybrid Grant-Loan Models ......................................... 39

6.5 General Advantages and Challenges to Feed-in-Tariffs ........................................................ 39

6.6 Comparison of Regulatory Streamlining and Permitting Assistance Programs ......................... 39

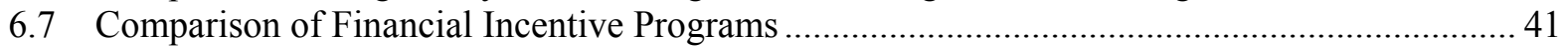

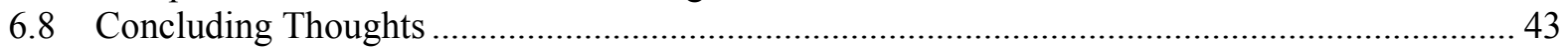

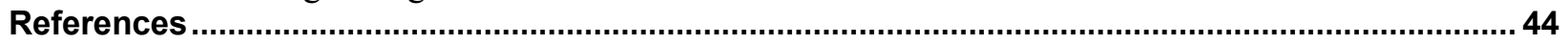

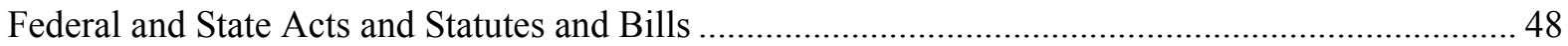

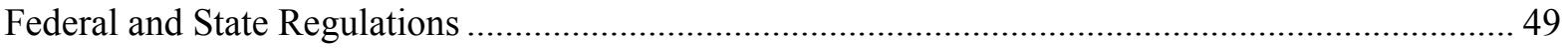




\section{Introduction}

State renewable portfolio standards (RPSs) ${ }^{1}$ and recent federal initiatives, ${ }^{2}$ such as the 2013 Hydropower Regulatory Efficiency Act (HREA), ${ }^{3}$ encourage the development of small hydroelectric generation. These policy trends, coupled with the amount of untapped hydroelectric potential, are accelerating interest in small hydropower development. (The definition of small hydropower development is discussed further in section 2 [DOE 2015.]) Yet, the capital costs associated with feasibility studies and permitting often "detract investor interest" in small hydropower development (NHA 2009; Warren 2017; Warren 2013).

In response to growing hydropower development inquiries and in recognition of the barriers associated with hydropower permitting, a number of state governments have established policies and programs to support small hydropower development. Although primarily led by federal agencies and national laboratories, states have funded and conducted hydropower resource studies. States have also led regulatory streamlining efforts that coordinate and expedite state regulatory reviews required for Federal Energy Regulatory Commission (FERC) approval and have implemented financial policy incentives (e.g., low-interest loans, loan guarantees, grants, and feed-in-tariffs) to support small hydropower development (Memo 2010; $2012 \mathrm{Vt}$. Acts \& Resolves 165; H.B. 2785, $74^{\text {th }}$ Leg., Reg. Sess. [Or. 2007]).

This report analyzes state-led initiatives that identify hydropower resources, simplify state and federal permitting processes, and provide financial assistance for small hydropower projects. Analyzing the history and utilization of each initiative, this report highlights the advantages and challenges of state small hydropower programs. This analysis hopes to assist state regulators interested in developing similar initiatives and inform project developers of the state incentives available for small hydropower development.

Section 2 provides additional background information on federal and state policy and regulatory trends.

Section 3 discusses state-led resource assessments for small hydropower development potential in the United States.

\footnotetext{
${ }^{1}$ As of February 2017, 29 states and the District of Columbia allow some form of small hydroelectric generation in their RPSs. DSIRE, Renewable Portfolio Standard-Hydroelectric Map, available at http://programs.dsireusa.org/system/program/maps (last visited Feb. 16, 2017).

${ }^{2}$ Hydropower Regulatory Efficiency Act of 2013, PL 113-23, 127 Stat. 493 (Aug. 9, 2013) (codified in scattered sections of 16 U.S.C.) (expands the category of hydroelectric facilities that qualify for an exemption, promotes conduit hydropower projects, and requires FERC to examine the feasibility of a two-year licensing process), Bureau of Reclamation Small Conduit Hydropower Development and Rural Jobs Act, PL 113-24, 127 Stat. 498 (Aug. 9, 2013); (authorizes nonfederal hydropower development at all Bureau of Reclamation sites, and provides a preference for existing project sponsors in developing hydropower), Consolidated and Further Continuing Appropriations Act, 2013, PL 113-6, 127 Stat. 198 (Mar. 26, 2012); (provides new funding for the DOE to expand hydropower development at existing dams, as authorized under the Energy Policy Act of 2005).

${ }^{3}$ Hydropower Regulatory Efficiency Act of 2013, PL 113-23, 127 Stat. 493 (Aug. 9, 2013) (codified in scattered sections of 16 U.S.C.) (expands the category of hydroelectric facilities that qualify for an exemption, promotes conduit hydropower projects, and requires FERC to examine the feasibility of a two-year licensing process).
} 
Section 4 discusses state-led regulatory streamlining initiatives affecting small hydropower development in the United States.

Section 5 discusses state policy providing financial incentives for small hydropower development in the United States.

Section 6 compares the benefits and challenges of each state regulatory and financial initiative. 


\section{Background}

This section provides further information on the concept of "small" hydropower, federal and state legislation generally supporting small hydropower development, and current small hydropower market conditions and trends.

\subsection{Small Hydropower Defined}

In the United States, there is no uniform definition of "small" hydropower. ${ }^{4}$ The definition of small hydropower varies in terms of capacity and system design but is generally defined by generating capacity with upper limits of 10-30 MW. Among national and international agencies, there is a growing consensus that "small hydropower" is defined as having a capacity less than $10 \mathrm{MW}$ (Kelly-Richards et al. 2017). The U.S. Department of Energy (DOE), ${ }^{5}$ the International Renewable Energy Agency, ${ }^{6}$ and the United Nations Industrial Development Organization ${ }^{7}$ have all defined small hydropower as $10 \mathrm{MW}$ or less (Kelly-Richards et al. 2017).

U.S. federal law and many state governments define small hydropower to include both capacity and system design restrictions. The Code of Federal Regulations (CFR), 18 C.F.R. $§ 4.30(b)(31)$, defines a "small hydroelectric power project" as $10 \mathrm{MW}$ or less that utilizes an existing dam or existing natural water feature and would not require the development of a new dam or impoundment. The CFR also defines a "small conduit hydroelectric facility" as $40 \mathrm{MW}$ or less that utilizes an existing conduit primarily used for purposes other than power production (18 C.F.R. $\S 4.30[\mathrm{~b}][20])$. In the United States, state governments tend to define small hydropower in terms of RPS eligibility, with upper capacity limits of $30 \mathrm{MW}$, varying positions on resource and technology limitations (e.g., existing infrastructure and new impoundment development), and varying positions on low-impact hydropower certification requirements (DOE 2016).

\subsection{Federal and State Legislative Efforts Generally Supporting Small Hydropower Development}

Federal legislation enacted in the $113^{\text {th }}$ Congress, including the Hydropower Regulatory Efficiency Act (HREA) ${ }^{8}$ and the U.S. Bureau of Reclamation (BOR) Small Conduit Hydropower Development and Rural Jobs Act (Rural Jobs Act) ${ }^{9}$ encouraged development of small

\footnotetext{
${ }^{4}$ Sarah Kelly-Richards et al., Governing the transition to renewable energy: A review of impacts and policy issues in the small hydropower boom, 101 Energy Policy 251, 264 (2017) (discussing in part the confusion in small hydropower definitions and the lack of knowledge and acknowledgement of small hydropower's social, environmental and cumulative impacts).

${ }^{5}$ U.S. Department of Energy, Hydropower Vision Study 73 (2016) (defining small hydropower as $10 \mathrm{MW}$ or less).

${ }^{6}$ International Renewable Energy Agency (IRENA), Roadmap for a Renewable Energy Future, 2016 Edition 39, 54 (2016) (defining small hydropower as 10 MW or less).

${ }^{7}$ Liu, H., Masera, D. and Esser, L., World Small Hydropower Development Report 2013, United Nations Industrial Development Organization: International Center on Small Hydropower viii (2013) (defining small hydropower as 10 MW or less).

${ }^{8}$ Hydropower Regulatory Efficiency Act of 2013, PL 113-23, 127 Stat. 493 (Aug. 9, 2013) (codified in scattered sections of 16 U.S.C.) (expands the category of hydroelectric facilities that qualify for an exemption, promotes conduit hydropower projects, and requires FERC to examine the feasibility of a two-year licensing process).

${ }^{9}$ Bureau of Reclamation Small Conduit Hydropower Development and Rural Jobs Act, PL 113-24, 127 Stat. 498 (Aug. 9, 2013) (authorizes nonfederal hydropower development at all Bureau of Reclamation sites, and provides a preference for existing project sponsors in developing hydropower).
} 
hydropower generation. HREA created a "regulatory off-ramp" from FERC permitting requirements for small (5 MW or less) existing conduit hydropower projects (Sale 2014). HREA also increased the FERC conduit exemption from licensing to $40 \mathrm{MW}$ and increased the small hydropower exemption from $5 \mathrm{MW}$ to $10 \mathrm{MW}$. In addition, the Rural Jobs Act authorized small (less than $5 \mathrm{MW}$ ) conduit power projects on BOR-owned infrastructure, while providing irrigation districts and water user associations the first right to develop hydropower projects. The Rural Jobs Act also directed the BOR to use a categorical exclusion to the National Environmental Policy Act for small conduit project applications (Sale 2014).

State RPSs may also influence small hydropower development. Sixty percent of all growth in renewable electricity generation since the year 2000 is associated with state RPSs (Barbose 2016). State RPS programs create renewable energy markets that can provide additional value to hydropower and incentivize development (DOE 2016). Renewable energy markets capture the environmental attributes of renewable energy and reward renewable generation in the form of renewable energy credits (RECs) ${ }^{10}$ (EPA 2017). As of February 2017, 29 states, the District of Columbia, and three territories ${ }^{11}$ have mandatory RPSs that include some form of eligible hydropower generation and offer financial incentives through renewable energy markets (DSIRE 2017b). The value of a REC varies between state and regional RPS compliance markets. As of 2016 , the value of a REC in Texas was “... approximately $\$ 1 / \mathrm{MWh}$ and nearly $\$ 60 / \mathrm{MWh}$ in ISO New England ${ }^{12}$ states" (DOE 2016).

Although REC pricing may be attractive in some compliance markets, hydropower is not always eligible to participate (DOE 2016). State ${ }^{13}$ RPS-eligible hydropower varies in terms of capacity limits, in-service restrictions, resource and technology limits (e.g., existing infrastructure, new dam development, capacity updates, or efficiency improvements), and explicit environmental and operational criteria such as certification by the Low Impact Hydropower Institute ${ }^{14}$ (DOE 2015; DSIRE 2017b; Barbose 2016; DOE 2016; Zayas et al. 2016). All states that allow hydroelectric generation in their RPS allow some type of "small" hydropower (DSIRE 2017a; DSIRE 2017b). State ${ }^{15}$ RPSs define small hydropower differently, but generally upper capacity limits range from $10 \mathrm{MW}$ for new development and $30 \mathrm{MW}$ for existing facilities ${ }^{16}$ (DOE 2016;

\footnotetext{
10 "A renewable energy credit (REC) is a market-based instrument that represents the property rights to the environmental, social and other non-powered attributes of renewable energy generation. RECs are issued when one megawatt-hour of electricity is generated and delivered to the electricity grid from a renewable energy source." (EPA 2017).

11 The three territories with mandatory RPSs include Puerto Rico, the U.S. Virginia Islands, and the Northern Mariana Islands.

12 ISO-New England states include Maine, Vermont, New Hampshire, Massachusetts, Connecticut, and Rhode Island.

${ }^{13}$ Includes the District of Columbia and U.S. territories.

${ }^{14}$ Low Impact Hydropower Institute (LIHI), a nonprofit corporation, established a certification process for existing hydropower plants that have avoided or reduced their environmental impacts pursuant to LIHI criteria.

${ }^{15}$ Includes the District of Columbia and U.S. territories.

${ }^{16}$ See e.g., CAL. PUB. RES. CODE REGS. $§ \S 25740-25751$ (2015) (state RPS includes small hydroelectric generation of 30 megawatts or less..."); COLO. REV. STAT. § 40-2-124 (2004) (state RPS includes new hydroelectricity with a nameplate capacity of 10 megawatts or less, and existing hydropower of 30 megawatts or less); 2013 Conn. Pub. Acts 13-303 (state RPS includes “...run-of-river hydropower facility that began operating after July, 1, 2003 and has a generating capacity of not more than 30 megawatts...”); 26-3000-3008 DEL. ADMIN. CODE $§ 1$ (2013) (state RPS includes "...hydroelectric facility that has a maximum design capacity of 30 megawatts or less..."); MD. CODE REG. $\S \S 7-701$ et seq. (2004) (state RPS includes “small hydroelectric power plant of less than 30 megawatts...”).
} 
Hydro Reform 2014). States with aggressive RPSs, such as Vermont and California, encourage hydroelectric generation from new and existing facilities. Vermont requires that the states' retail electricity suppliers obtain $75 \%$ of their annual electricity from renewable sources, which includes any size hydroelectric facility, by 2032 (2015 Vt. Acts \& Resolves 56). Similarly, California requires that the state's retail electricity suppliers obtain $50 \%$ of their annual electricity sales from renewable resources, which includes hydroelectric facilities of $30 \mathrm{MW}$ or less, by 2030 (CAL. PUB. RES. CODE REGS. §§ 25740-25751 [2015]).

\subsection{Current Market Conditions and Trends}

Current electricity market conditions may be challenging for small hydropower development. According to FERC, during 2016, average day-ahead on-peak electric prices reached near record lows, with prices ranging from $\$ 23 / \mathrm{MWh}$ to $\$ 35 / \mathrm{MWh}$, driven primarily by low prices for natural gas (FERC 2017). In addition, avoided cost $\operatorname{rates}^{17}$ for qualifying facilities ${ }^{18}$ under the Public Utility Regulatory Policy Act (PURPA) have experienced a downward pricing trend, making it difficult for small hydropower generation to compete against other types of qualifying facilities ${ }^{19}$ (Maloney 2017).

Hydropower capacity growth has been limited in recent years. Installed U.S. hydropower capacity increased by approximately $200 \mathrm{MW}$ in 2015, with most of the increase originating from capacity increases at existing facilities (DOE 2017a). In 2016, at least nine projects (totaling $225 \mathrm{MW}$ ) came online, the majority of which were less than $10 \mathrm{MWs}$. Three of the nine projects, totaling $211 \mathrm{MW}$, were located on existing non-powered dams on the Ohio River (Martínez, Johnson, and O’Connor 2017).

These market trends have made the economics of developing hydropower in the United States more difficult and have increased the importance of federal and state permit streamlining and financial assistance programs for developers of new hydropower projects.

\footnotetext{
${ }^{17}$ PURPA requires regulated utilities to purchase energy and capacity from qualifying facilities at the utilities' "avoided cost." Avoided cost means "the incremental costs to an electric utility of electric energy or capacity or both which, but for the purchase from the qualifying facility or qualifying facilities, such utility would generate itself or purchase from another source." 18 C.F.R. $\S 292.101(b)(6)$.

18 A PURPA qualifying facility includes both "cogeneration" and "small power production" facilities. 18 C.F.R $\S$ 292.101(b)(1). Small power production facilities include (with limited exceptions) generating facilities of $80 \mathrm{MW}$ or less whose primary source is hydropower, wind, solar, biomass, waste, or geothermal resources. 16 U.S.C. $\S$ $796(17)(\mathrm{E})$.

${ }^{19}$ Since 2015, state public utility commissions have received a number of petitions from PURPA regulated utilities seeking to cut avoided cost rates as well as shorten contract term lengths. For example, in June of 2017 the Montana Public Service Commission cut avoided cost rates by $40 \%$ and reduced contract lengths for qualifying facilities from 25 years to 5 years with an additional 5 -year option.
} 


\section{Resource Assessments}

In 2016, the hydropower fleet in the United States produced more than 6\% (approximately 265,829 gigawatt-hours [GWh]) of the total net electricity generation (Martínez, Johnson, and O'Connor 2017). The median-size hydroelectric facility in the United States is $1.6 \mathrm{MW}$, and $75 \%$ of the facilities have a nameplate capacity of $10 \mathrm{MW}$ or less (DOE 2015). Moreover, the United States has considerable hydroelectric potential beyond what is already developed (DOE 2016; Kao 2014; Hadjerioua 2012; Sale 2014). Federal resource assessments have found approximately $79 \mathrm{GW}$ of untapped hydroelectric potential at low-impact new stream-reaches, ${ }^{20}$ non-powered dams, ${ }^{21}$ and existing conduits, ${ }^{22}$ much of which has a median project size of 10 MW or less. The DOE's Hydropower Vision study modeled a scenario where $49 \mathrm{GW}$ of this hydroelectric potential was deployable by 2050 (DOE 2016). In addition, states including California, Colorado, Maine, and Oregon have conducted assessments identifying a significant amount of small hydropower resource potential within their respective state. These federal and state resource assessments inform development opportunities, as well as policy and programming (e.g., RPS criteria, financing options, and regulatory streamlining efforts) advancing small hydropower development.

At the federal level, DOE has funded several resource assessments by Oak Ridge National Laboratory (ORNL). In 2012, ORNL identified approximately $12 \mathrm{GW}$ of hydropower potential at non-powered dams at 54,391 prospective project sites. Approximately 2,556 MW of the potential identified has a median project size of $10 \mathrm{MW}$ or less (Hadjerioua 2012). In 2014, ORNL identified $65 \mathrm{GW}$ of hydroelectric potential at new stream-reaches, of which 8,500 MW were at small sites (1 MW or less) (Kao 2014; Johnson 2015). Another 2014 ORNL study identified approximately 1-2 GW of small hydroelectric potential at existing conduits, of which $104 \mathrm{MW}$ were at 373 BOR-owned canals (Sale 2014).

At the state level, several states have completed hydropower resource assessments. A 2006 study issued by the California Energy Commission found approximately $225 \mathrm{MW}$ of RPS-eligible ${ }^{23}$ small hydropower in man-made conduits across the state (Navigant 2006). Similarly, multiple resources studies in Colorado found approximately $30 \mathrm{MW}^{24}$ of small hydropower potential at

\footnotetext{
${ }^{20}$ S. Kao et al., ORNL, New Stream-reach Development: A Comprehensive Assessment of Hydropower Potential in the United States 25, 33, 41, 51, 59, 75 (2014) (identifying approximately $65 \mathrm{GW}$ of new stream reach hydropower development at more than 3 million U.S. streams taking into account "environmental attribut[e]s...natural ecological systems; social and cultural settings; and policies, management and legal constraints").

${ }^{21} \mathrm{See}$ B. Hadjerioua et al., U.S. Department of Energy, An Assessment of Energy Potential at Non-Powered Dams in the United States (2012) (identifying more than 50,000 suitable non-powered dams with technical hydropower potential of $12 \mathrm{GW})$.

${ }_{22}^{2}$ See M. Sale et al., Oak Ridge National Laboratory, Opportunities for Energy Development in Water Conduits: A Report Prepared in Response to Section 7 of the Hydropower Regulatory Efficiency Act of 2013 (2014) (finding approximately 1-2 GW of hydropower potential at existing canals and conduits nationwide).

${ }^{23}$ In 2006, California's RPS restricted eligibility of small hydropower facilities (30 MW or less) to those did not require "...a new or increased appropriation or diversion of water..." 2002 Cal. Stat. 399.12(e)(1)(A)-(B).

${ }^{24}$ Colorado Department of Agriculture, Recommendations for Developing Agricultural Hydropower in Colorado (Dec. 15, 2013) (estimating that 175,000 acres of the state's irrigated farmland is suitable for new, pressurized irrigation and installation of small hydropower plants with $30 \mathrm{MW}$ of potential from these systems).
} 
agricultural irrigation systems and 20-25 $\mathrm{MW}^{25}$ of small hydropower potential at existing municipal water systems ${ }^{26}$ (Colorado Energy Office 2016; Applegate Group, Inc. 2013). Multiple resource studies in Oregon also found a substantial amount of small hydropower potential at irrigation systems across the state ${ }^{27}$ (Perkins 2013; Black Rock Consulting, LLC. 2010; Summit Blue Consulting, LLC. 2009). Alternatively, a Maine 2015 resource study focused on conventional small hydropower, identifying $110 \mathrm{MW}$ through efficiency upgrades at existing hydropower facilities and non-powered dams within the state (Kleinschmidt 2015).

${ }^{25}$ Colorado Energy Office, Colorado PRV-Hydropower Assessment 14 (2016) (finding 20-25 MW of small hydropower potential by replacing pressure reducing valves with turbines at existing municipal water systems across the state).

${ }^{26}$ In 2015, in part due to the results of this study, the Colorado Department of Agriculture applied for funding from the U.S. Department of Agriculture to develop a grant program (RCPP Pressurized Irrigation Small Hydropower Partnership Project [RCPP Irrigation Hydropower Program]) to support small agricultural hydropower project development (discussed further in 5.2).

${ }^{27}$ The results of these studies, in part, informed Energy Trust's decision to provide more funding for feasibility studies and conduit hydropower development (discussed further in 4.2). 


\section{Regulatory Streamlining and Permitting Assistance Initiatives}

State-led regulatory streamlining efforts are promoting small hydropower development.

Simplifying federal and state permitting lowers costs and reduces the amount of time required for approval, increasing the economic feasibility of developing small hydropower (FERC 2009). Programs in Colorado, Vermont, and Oregon expedite state regulatory reviews required for FERC approval and provide permitting assistance. State legislative directives are the most common implementation vehicles for regulatory efficiency and permitting assistance efforts. The design, administration, and operation of these initiatives vary. Legislative mandates in Vermont and Oregon task existing state regulatory agencies with administrative responsibilities, while in Colorado a non-regulatory office of the governor oversees the streamlining efforts. Other legislative designs in Oregon direct an independent, nonprofit organization to administer the program with oversight from the state public utility commission.

\subsection{State-Agency-Implemented and Operated Program Models}

State legislative mandates, like those in Colorado, Vermont, and Oregon, often direct existing agencies to implement regulatory streamlining efforts and/or provide funding for feasibility studies, project design, and permitting assistance to promote small hydropower development.

\subsubsection{Colorado: Streamlined Federal Permitting Assistance Service for Small Hydropower}

\subsubsection{Implementation History and Process}

In 2010, the State of Colorado and FERC entered into a Memorandum of Understanding (MOU) to encourage the development of small hydropower. Prompted by federal surveys identifying a substantial amount of small hydropower potential, Colorado recognized the MOU as an important step towards meeting the state's RPS mandate. In order to develop Colorado's small hydropower potential in an efficient and cost-effective manner, the MOU established a pilot program to simplify the regulatory review of small hydropower projects (Memo 2010).

To coordinate efforts, Colorado and FERC identified a single point of contact for implementation of the pilot program: the Colorado Energy Office (CEO) within the Colorado Office of the Governor. Designated to guide and educate potential program applicants, the CEO reviewed exemption applications for completeness and compliance. Helping to create the framework for HREA and Colorado's current streamlined federal permitting assistance service, the MOU required the pilot program to prescreen proposed hydropower projects. The prescreening process was intended to streamline the pre-filing consultation process for small hydropower projects by ensuring exemption applications were complete before submission to FERC. The prescreening process was also supposed to certify that the proposed project would use existing infrastructure - for which hydropower was an incidental use - and would not increase water diversion or result in adverse environmental effects. After prescreening, the pilot program required the CEO to submit the exemption application to relevant resource agencies for review and comments as required by 18 C.F.R. $\S 4.38(c)(5)$. The CEO also had to file any terms and conditions prescribed by the state fish and wildlife agency and encouraged federal agencies to file conditions within ten days of any application for a small hydropower project prescreened as part of the pilot program (Memo 2010). 
FERC then agreed to act on the application within 30 days and either request additional information, issue a deficiency letter, or issue a notice of acceptance of the application. FERC agreed to waive the first and second stages of consultation if all relevant resource agencies and any affected Indian tribes agreed to do so. If FERC issued a waiver, the MOU provided for an accelerated schedule of milestones so the application could be processed and issued as quickly as possible (Memo 2010).

The pilot program structure and the eventual implementation of HREA prompted the 2014 Colorado Legislature to pass a bill streamlining state environmental review for small hydropower projects. The 2014 legislation requires the CEO to provide streamlined permitting assistance to qualifying small hydropower projects. The legislation authorizes CEO to coordinate state agencies to facilitate timely review of proposed hydropower projects. In line with the initial pilot program, the CEO coordinates and compiles state agency comments when qualifying small hydropower projects apply for a FERC exemption or authorization (COLO. REV. STAT. § 24-38.5108 [2014]).

In contrast to the initial pilot program, the qualifying criteria for Colorado's streamlined permitting assistance reflect changes made by HREA, including FERC authorizations: ${ }^{28}$ increasing the conduit exemption to $40 \mathrm{MW}^{29}$ and increasing the $5 \mathrm{MW}$ exemption to $10 \mathrm{MW}$. In addition, the streamlined permitting assistance does not include a prescreening process. The developer must determine whether the proposed project qualifies for a FERC exemption or authorization, submit the appropriate Notice of Intent to FERC, and then contact the CEO regarding the project. Afterwards, the CEO hosts a meeting with the developer and the relevant state agencies regarding the proposed project and establishes deadlines for comment submissions. After the state agencies review the project and provide comments and/or initial mandatory conditions, the CEO compiles the comments and conditions and submits the information to FERC for review (COLO. REV. STAT. § 24-38.5-108 [2014]).

In 2016, the CEO began an initiative to support the development of small hydropower at existing conduit systems that utilize pressure-reducing valves (PRVs). Prompted by a 2016 PRVHydropower Assessment, ${ }^{30}$ the CEO began to sponsor technical workshops to help attendees identify viable municipal hydropower projects within their water delivery systems. Under the new PRV-initiative the CEO has also offered developers streamlined permitting assistance services. As of mid-2017, the CEO has received 26 initial FERC applications for streamlined permitting assistance, out of which nine hydropower projects submitted complete applications and six ultimately received FERC conduit exemptions. Since the first PRV workshop in December 2016, the CEO has also helped facilitate the submission of 12 PRV-specific FERC qualifying conduit applications totaling $800 \mathrm{~kW}$ in expected generation (Reifer 2017).

\footnotetext{
${ }^{28}$ Hydropower Regulatory Efficiency Act of 2013, PL 113-23, 127 Stat. 493 (Aug. 9, 2013) (removed "qualifying conduit facilit[ies]" from FERC licensing jurisdiction under 30(a) of the Federal Power Act (FPA) (i.e., nonjurisdictional) and replaced the licensing/exemption process with a 60-day Notice of Intent process).

${ }^{29}$ Hydropower Regulatory Efficiency Act of 2013, PL 113-23, 127 Stat. 493 (Aug. 9, 2013) (amending section 30 of the FPA to allow small conduit exemptions on federal lands, and to increase the maximum installed capacity for all small exemptions to $40 \mathrm{MW}$ [previously non-municipal projects were limited to $15 \mathrm{MW}$ ]).

${ }^{30}$ Colorado Energy Office, Colorado PRV-Hydropower Assessment 14 (2016) (finding 20-25 MW of hydropower potential by replacing PRVs with small hydropower turbines).
} 
The CEO's permitting assistance supported the Meeker Wenschhof project located in Rio Blanco County, Colorado. The $23-\mathrm{kW}$ project yields annual generation of approximately $100,000 \mathrm{kWh}$, utilizing water for irrigation to produce power that will offset the electricity consumption of an irrigation sprinkler. The project provides a rural Colorado rancher new revenue in the form of electricity savings (Reifer 2017).

\subsubsection{Advantages}

By coordinating resource agency reviews, and providing a single point of contact for developers, Colorado's streamlined permitting assistance service has the potential to reduce the time it takes to obtain a FERC exemption or authorization. Providing an opportunity for state agencies to meet with the developer at the same time streamlines information gathering and reduces duplicative inquires that are common when a developer works with a state agency independently. This upfront meeting also ensures adequate consultation with state agencies required by the Federal Power Act and that state agency comments and/or initial mandatory conditions do not conflict with one another before submission to FERC for review.

\subsubsection{Challenges}

In practice, utilization rates for the streamlined permitting assistance service are low. Research points to the implementation and design of the service as a possible cause for inefficiencies and low utilization rates. The Colorado Legislature gave the CEO, a non-regulatory agency, the responsibility of implementing and administering the service. The CEO can encourage coordinated communications and meetings with resource agencies and timely review, but the CEO does not have the authority to mandate such actions. In addition, lack of awareness and interest in the service also seems to account for low utilization. Lack of interest in the permitting assistance may stem from current market conditions and the fact that many conduit projects in Colorado are located on BOR property, which qualify for a lease of power privilege. However, with the CEO's new PRV-hydropower initiative the permitting assistance service has seen an uptick in utilization, and continued outreach and future technical workshops identifying municipal conduit potential may ensure this trend continues.

\subsubsection{Vermont: Small Hydropower Assistance Program}

\subsubsection{Implementation History and Process}

In 2012, the Vermont General Assembly passed Act 165 (S.148) to encourage micro and small hydropower development. Prompted by reports that identified $434 \mathrm{MW}$ of small (5 MW or less) hydropower potential in Vermont, Act 165 sought to advance the state's existing renewable energy policy ${ }^{31}$ by alleviating some of the costs associated with hydropower permitting. ${ }^{32}$ Looking to Colorado's MOU with FERC as a model, Act 165 directed the Vermont Public Service Department (VPSD) to enter into a MOU with FERC to simplify the regulatory review process for small hydropower projects (VPSD 2014).

After passage of Act 165, the VPSD, in consultation with the Vermont Agency of Natural Resources (VANR) and the State Historic Preservation Office of the Agency of Commerce and

\footnotetext{
${ }^{31}$ S. 148, 2011-2012 Gen. Assemb., Reg. Sess. (Vt. 2012), enacted 2012 Vt. Acts \& Resolves 165. (promoting the development and use of renewable energy projects, including hydroelectric projects.)

${ }^{32}$ S. 148, 2011-2012 Gen. Assemb., Reg. Sess. (Vt. 2012), enacted 2012 Vt. Acts \& Resolves 165. (recognizing the length and cost associated with obtaining FERC approval as prohibitive to small hydropower development).
} 
Community Development (VACCD), met regularly to implement the Act. The "Interagency Hydro Team" 33 (Team) reviewed each agency's statutory responsibilities in the hydropower permitting process and held discussions with the Colorado Governor's Energy Office regarding Colorado's MOU with FERC. The Team also consulted with FERC to understand existing pathways within the Federal Power Act to expedite permitting (VPSD 2014).

FERC staff indicated that a major cause of delay in issuing a FERC license or exemption is receipt of incomplete applications, along with inadequate state and federal agency consultation. Incomplete applications and inadequate pre-filing consultation results in additional time for FERC to request, receive, and review information from applicants as well as for the resource agencies to complete their reviews and develop comments (VPSD 2014).

FERC and the Colorado Governor's Energy Office informed the Team that a MOU between FERC and Vermont was not necessary. The Colorado-FERC MOU did not amend actual law or practice of federal hydropower regulation. The Colorado-FERC MOU's major achievements were to enhance and formalize upfront communication with applicants, stakeholders, state agencies, and FERC. The Colorado-FERC MOU also assisted developers by providing a technical and permitting consultant, and coordinating interagency review and feedback in order to give FERC the information and assurances necessary for FERC to pursue a shortened review timeline (VPSD 2014).

The Team concluded the best way to achieve the goal of Act 165 was to provide greater assistance to developers early on in a project, coordinate communications, and identify projects prime for expedited approval. The Team created a state interagency MOU, fully executed by the VPSD, the VANR, and the VACCD in July 2013. The MOU provides for enhanced coordination, identification, and assistance for developers of low-impact projects of high public value (such as those owned by public entities and those utilizing existing infrastructure), and provides the following types of assistance:

- Designates a point person at each agency who will be responsible for assisting developers of low-impact ${ }^{34}$ hydropower projects

- Coordinates interagency site visits for potential FERC applicants in order to assess potential projects and apprise them of issues that will need to be addressed in the application process

- Provides informational materials to assist hydropower developers

\footnotetext{
${ }^{33}$ Interagency Hydro Team included representatives from the Vermont Public Service Department, the Vermont Agency of Natural Resources, and the Vermont State Historic Preservation Office of the Agency of Commerce and Community Development.

${ }^{34}$ Vermont classifies "low-impact" as projects that: are not located on Class A waters, Outstanding Resource waters, or federally or state protected river reaches; are located at an existing dam, or do not require a dam or other impoundment; will be located on lands controlled by the applicant or that demonstrate support from the adjoining landowner; do not increase the impoundment elevation, are run-of-river; and have bypass flows that meet the hydrologic standards defined by Vermont Agency of Natural Resources.
} 
- Coordinates and continually engages with FERC in this process to ensure state actions and policies will be useful in developing better applications and will be complementary to the FERC process.

The Team submitted the first iteration of a biennial report required by Act 165 in January 2014, describing the implementation of the Act's directive and the resulting interagency MOU. The legislature encouraged the Team to proceed with the development of the Vermont Small Hydropower Assistance Program, which the Team rolled out in the summer of 2015 (VPSD 2016).

The Vermont Small Hydropower Assistance Program is an optional program that provides enhanced assistance from the VANR, the VPSD, and the VACCD for small-low impact projects. The program is designed to provide an expedited review process for small-low-impact hydropower projects in accordance with HREA. If the proposed project passes the initial desk review, ${ }^{35}$ the VANR, the VPSD, and the VACCD conduct a multiagency site visit to determine whether the project qualifies for enhanced state assistance. Enhanced assistance includes waiving pre-filing consultation, supporting shorter comment periods, and/or issuing a letter to FERC indicating that the state agency requirements are satisfied (VPSD 2016).

\subsubsection{Advantages}

Vermont's Small Hydropower Assistance Program has the potential to increase efficiencies in state and federal regulatory review, which should decrease the time and cost associated with small hydropower permitting. Fundamentally, the legislative design utilizes existing regulatory structures by directing the three primary state agencies (VANR, VPSD, and VACCD) involved in hydropower permitting to create and administer the program. These state agencies have the statutory authority to implement efficiency measures in their own review processes for hydropower development.

By providing a prescreening process, facilitating a multiagency site visit, and coordinating resource agency reviews, Vermont's Small Hydropower Assistance Program has the potential to reduce the time it takes to obtain a FERC exemption or authorization. The program's initial prescreening process streamlines the pre-filing consultation process for small hydropower projects by ensuring a proposed project qualifies for a FERC exemption and that an exemption application is complete before submission to FERC. The Interagency MOU requiring multiagency site review reduces the time necessary for preliminary assessments and encourages upfront communication between the resource agencies. Providing an opportunity for these agencies to meet with the developer at the same time streamlines information gathering, reducing duplicative inquires that are common when a developer works with a state agency independently. In addition, this upfront interaction also ensures adequate consultation with state agencies required by the Federal Power Act and that state agency comments and/or initial mandatory

\footnotetext{
${ }^{35}$ To qualify for a multiagency site visit, the project must demonstrate it can meet all prescreening requirements (e.g., the project will not be located on a Class A waters, Outstanding Resource Waters, or federally or state protected river reaches, the project will be located at an existing dam, or the project will not require a dam or other impoundment, the project will be located on lands approved by adjoining landowner or owned by applicant, the project will not increase the impoundment elevation, will be operated as a true run-of-river project, and will meet hydrologic standards for bypass flows).
} 
conditions do not conflict with one another before sending them to FERC for review (VPSD 2016).

\subsubsection{Challenges}

The VPSD noted that as of July 2017, no projects have utilized the Vermont Small Hydropower Assistance Program. Although the program is relatively new, the VPSD noted the greatest challenge seemed to be a gap in need. "Those more experienced, larger developers do not need regulatory assistance. Those less experienced, smaller developers that would utilize the program cannot find the financing [required] so the projects are cost prohibitive..." (Margolis 2017). The lack of awareness of the program and a low number of viable development locations may also account for low utilization.

\subsubsection{Oregon: Existing Water Rights Expedited Process}

\subsubsection{Implementation History and Process}

In 2007, the Oregon Legislature passed H.B. 2785 to encourage micro and small hydropower development. Prompted by Oregon's 2005 Renewable Energy Action Plan, which identified the opportunity for small hydropower development within irrigation canals, H.B. 2785 sought to support the state's newly passed RPS mandate ${ }^{36}$ by alleviating some of the costs associated with hydropower permitting (Oregon Department of Energy [ODOE] 2006). The legislation recognized that water rights holders, especially the largest, were the most likely to have access to the volumetric flows necessary to develop economically viable hydropower. In order to develop this hydropower potential in an efficient and cost-effective manner, H.B. 2785 established an expedited water rights review process for certain small conduit hydropower projects with existing water rights (H.B. 2785, $74^{\text {th }}$ Leg., Reg. Sess. (Or. 2007) (codified in OR. REV. STAT. $\S \S$ 543.765 [2013]).

Specifically, the legislation allows water rights holders to apply for a change of use to operate small hydropower projects through an expedited process while not losing the priority date associated with their original water right. By piggybacking on existing water right diversions, a developer can bypass the requirement to obtain a new water right, significantly shortening the permitting process (Summit Blue Consulting, LLC. 2009). To qualify for an expedited review a proposed project must hold an existing water right for purposes other than hydropower generation and

- Have a hydroelectric generating capacity of $5 \mathrm{MW}$ or less and utilize an existing dam or

- Be an in-conduit non-municipal project of $15 \mathrm{MW}$ or less or

- Be an in-conduit municipal project of $40 \mathrm{MW}$ or less (OR. REV. STAT. $§ 543.765$ [1][a][b] [2013]).

In addition, applicants must provide documentation of their original water right, proof that the proposed project will maintain the original rate of water use, and verify the proposed

\footnotetext{
${ }^{36}$ S.B. 838, 74 ${ }^{\text {th }}$ Leg., Reg. Sess. (Or. 2007) (enacted) (requiring Oregon's large electric investor-owned utilities to acquire $25 \%$ of electric load from qualifying renewable energy resources, which includes small hydroelectric resources by 2025), amended by S.B. 1547, $78^{\text {th }}$ Leg., Reg. Sess. (Or. 2016) (enacted) (raising the target to 50\% renewable energy by 2040).
} 
hydropower use does not impair and is not detrimental to the public interest (Energy Trust of Oregon 2009).

The law authorizes the Oregon Water Resources Department (OWRD) to issue a certificate appropriating water for hydropower purposes after notice to the Oregon Department of Fish and Wildlife and a 30-day public comment period (OR. REV. STAT. § 543.765[3]). After the 30-day comment period, OWRD reviews the application materials and public comments to confirm the proposed project is consistent with the public interest (Energy Trust of Oregon 2009). OWRD considers a variety of factors when making a public interest determination. The proposed project must not compromise the ability of the public to use the water for other purposes, hinder the ability to maximize the economic potential of the waters, compromise the state's ability to control waters, or conflict with vested water rights or Oregon's water resources policy. If OWRD confirms that the proposed project will not be detrimental to the public interest, OWRD may issue a final order approving the certificate to appropriate (Energy Trust of Oregon 2009).

As of mid-2017, approximately a dozen hydropower projects have utilized the expedited existing water rights process (Grainy 2017). For example, in 2012 OWRD issued a water rights certificate within 60 days through the expedited existing water rights process to Three Sisters Irrigation District for a 700-kW hydropower project in Sisters, Oregon (Thalacker 2017).

\subsubsection{Advantages}

The expedited review process significantly reduces the time it takes to obtain a certificate to appropriate water. Before implementation of the law, several agencies, including OWRD, the Oregon Department of Environmental Quality, the Oregon Department of Fish and Wildlife, and the Oregon Parks, reviewed certificate applications (H.B. 2785, 74 ${ }^{\text {th }}$ LEG. REG. SESS. [2007]). These reviews often required multiple public comment periods, instead of just one 30-day comment period required through the expedited process. In addition, the expedited process does not require a contested case hearing unless OWRD determines that the proposed project is detrimental to the public interest. Certain in-conduit projects also do not need to include a requirement for fish passage at the diversion point for the conduit (OR. REV. STAT. $\S 543.765[5)][\mathrm{b}])$. OWRD estimates that a thoroughly completed certificate application review for hydropower projects with an existing water right should take as little as two months to process (Energy Trust of Oregon 2009).

In addition, the projects eligible for the expedited process are not subject to the No Dead Fish Rule (OR. REV. STAT. §543.017[c]). The rule only applies in cases where the developer must obtain a new water right. In cases where the rule applies, the developer must prove that the proposed project will not result in any net loss of fish. Additional costs are associated with studies required for projects subject to the rule.

\subsubsection{Challenges}

The expedited process only applies to those with an existing water right, limiting project development options and utilization of the streamlined process. Developers that would otherwise be good candidates for small hydropower development may not hold an existing water right and do not benefit from the expedited process. The financial risks associated with not obtaining a water right often deter capital investment and overall project feasibility (Summit Blue Consulting, LLC. 2009). 
In turn, many existing water right holders do not have an interest in developing hydropower and do not utilize the expedited water right process. Moreover, all water rights holders that obtained their water right before the implementation of the Oregon Water Code (February 24, 1909) and that have used their water right continuously must go through an adjudication process (to certify the vested water right as a decreed right) to be eligible for hydropower development. The adjudication process involves comprehensive public involvement, providing opportunities for stakeholders to contest the claims to the water right. Some water right holders may find that "...the prospect of losing claim to any of their vested water rights is enough to deter them from pursuing certification" and ultimately hydropower development (Summit Blue Consulting, LLC. 2009).

\subsection{Independent, Nonprofit Implemented and Operated Program Models}

Some state legislative mandates, such as one found in Oregon, direct independent, nongovernmental entities to implement regulatory streamlining efforts, as well as fund feasibility studies, project design, and permitting assistance to promote small hydropower development.

\subsubsection{Oregon: Energy Trust of Oregon Small Hydropower Initiative}

\subsubsection{Implementation History and Process}

In 1999, the Oregon Legislature passed an electric-utility restructuring law, S.B. 1149, to introduce elements of competition in the retail markets of Oregon's two largest investor-owned utilities: Pacific Power Corporation (PacifiCorp) and Portland General Electric (PGE). To address concerns that the new law would discourage utility investment in energy efficiency and renewable energy S.B. 1149 created a fund to promote energy conservation programs, market transformation efforts, renewable energy resources, and low-income weatherization (S.B. 1149, $70^{\text {th }}$ Leg., Reg. Sess. [Or. 1999]; Ackerman 2013).

Specifically, the legislation requires PacifiCorp and PGE to collect a 3\% public purpose charge from "all electricity customers located within [the utilities] service area." The law directed the Oregon Public Utility Commission (OPUC) to establish rules to govern the collection of the public purpose charge and to allocate the funds. In part, the law requires the OPUC to allocate $19 \%$ of the revenue generated by the charge to "above-market costs for new renewable energy resources" and $63 \%$ to "new cost-effective conservation and new market transformation" programs (S.B. 1149, 70 ${ }^{\text {th }}$ Leg., Reg. Sess. [Or. 1999]).

In response to the allocation mandate, OPUC authorized the Energy Trust of Oregon (Energy Trust), an independent nonprofit organization, to administer a portion of the collected funds. The Energy Trust began operation in 2002, tasked by the OPUC with investing in new renewable energy resources, energy conservation projects, and market transformation (Energy Trust of Oregon 2014).

In 2007, the Oregon Legislature passed the Oregon Renewable Energy Act (Act), S.B. 838, extending the $3 \%$ public purpose charge from 2012 to 2025 . The Act also established a goal that $8 \%$ of Oregon's retail electric load comes from small-scale renewable energy projects by 2026. To support this goal, the Act modified the public purpose charge for renewables to require that 
funding be used to support projects of $20 \mathrm{MW}$ or less (S.B. 838, $74^{\text {th }} \mathrm{Leg}$., Reg. Sess. [Or. 2007]).

Energy Trust's renewable energy programs include financial incentives for small hydropower projects (20 MW or less) located in the service territory of, or that deliver power to, PGE or PacifiCorp in Oregon. Energy Trust provides support for project development, including, but not limited to, grant writing assistance, feasibility studies, final design, permitting, utility interconnection, and construction management. Energy Trust may pay up to $50 \%$ of the cost of hiring an outside consultant to provide expert assistance for these activities, up to a maximum of $\$ 200,000$ (Energy Trust of Oregon 2017). Through their energy efficiency programs, Energy Trust may also provide additional funds for energy savings that result from irrigation infrastructure improvements. Energy Trust provides funds on a reimbursement basis after project installation or activity completion (Jorgensen 2017). Energy Trust primarily focuses on small inconduit facilities at existing irrigation systems, in part, because multiple state resource studies ${ }^{37}$ have identified sites at irrigation diversions with the greatest hydropower potential and because these projects can often leverage additional funding sources related to other benefits, such as water conservation or other environmental improvements. As of mid-2017 Energy Trust has provided over \$10 million in funding to 111 small hydropower projects (Jorgensen 2017).

Three Sisters Irrigation District in Bend, Oregon, is an example of a project that utilized Energy Trust's program. In 2014, Energy Trust provided a \$1 million cash incentive to the Three Sisters Irrigation District to add a $700 \mathrm{~kW}$ hydropower plant as part of on-going irrigation modernization upgrades. The hydropower system generates about 3.1 million $\mathrm{kWh}$ of electricity annually. (Energy Trust of Oregon 2017).

In addition, in 2015 Energy Trust provided a \$900,000 cash incentive for Farmers Irrigation District in Hood River, Oregon, to replace two older turbines with a single, higher-efficiency 3-MW turbine and generator. By repowering the hydropower plant, Farmers Irrigation District increased generation by $12 \%$ and revenue by an estimated $\$ 130,000$, while also saving approximately $\$ 150,000$ on annual operations and maintenance costs (Energy Trust of Oregon 2017).

\subsubsection{Advantages}

Upgrading aging irrigation infrastructure in Oregon provides an opportunity to use an existing resource for the additional benefit of hydropower generation. As a program objective, focus on small in-conduit facilities at existing irrigation systems has a high project success rate for three main reasons. First, there is a lot of opportunity to develop small hydropower facilities at irrigation systems in Oregon. A 2013 Farmers Conservation Alliance (FCA) study, found that there are up to 70,000 irrigation diversions in Oregon, many of which have small-hydropower potential. Second, coupling agricultural infrastructure improvements with power generation has numerous ancillary benefits and increases funding opportunities. FCA found that small-scale

\footnotetext{
${ }^{37}$ Perkins, L., Farmers Conservation Alliance, Cumulative Watershed Impacts for Small-Scale Hydroelectric Projects in Irrigation Delivery Systems: A Case Study 3-4 (Jun., 2013) (“a great opportunity to generate significant amount of power exists given there are 55,000 to 70,000 irrigation diversions in Oregon"); see also Black Rock Consulting, Hydropower Potential and Energy Savings Evaluation 1 (Sept. 16, 2010) (citing an earlier 2008 study which identified irrigation water providers as one of the state's largest resources for the development of untapped hydropower potential).
} 
hydropower projects located within existing water delivery systems have "...positive impacts on the local economy, the watershed community, and watershed health." These projects, often located in rural areas, provide "... decentralized, locally produced power that is locally owned and operated." FCA found that this local connection usually meant a closer relationship with the local community. In addition, the revenue generated from the hydropower helps fund infrastructure improvements leading to "...increased summer stream flows, installation of fish screens, removal of [fish] passage barriers, and increased collaboration within the watershed community." Third, the environmental and local economic benefits associated also broaden public support. Energy Trust and FCA have found that developing hydropower at existing irrigation systems increases the likelihood of gaining support from the public. (Perkins 2013).

\subsubsection{Challenges}

Potential challenges associated with Energy Trust's hydropower initiative include:

- The potential difficulty of implementing a surcharge on electricity customers to fund continued programming, and

- The potential oversight and accountability concerns associated with an independent nongovernmental entity charged with implementing the fund being too far removed from direct oversight by the electorate. 


\section{State Financial Incentive Models}

States providing capital cost financial assistance for project development may increase the viability of small hydropower development (Energy Trust of Oregon 2017; Summit Blue Consulting, LLC. 2009). High capital costs can impede the development of small-scale hydropower. Offering an alternative to commercial lending institutions, states can provide lowcost, long-term financing solutions for small hydropower development. Low-cost, long-term financing can reduce initial capital costs by lengthening the period of time over which installation costs are paid and/or reducing interest rates (Lantz 2010). States such as Colorado, Oregon, Massachusetts, Rhode Island, and Vermont have implemented a number of financial incentives that support small hydropower development. These financial incentives include low interest loans, loan guarantees, grants, and feed-in-tariffs.

\subsection{Loan and Loan Guarantee Model}

Colorado and Oregon have developed loan and loan guarantee programs to encourage smallscale hydropower development. Low-interest loan opportunities and loan guarantees offered by state governments often offer more favorable loan terms and conditions than traditional lending institutions (Lantz 2010).

\subsubsection{Colorado: Water Project Loan Program}

\subsubsection{Implementation History and Process}

In 1971, the Colorado Legislature charged the Colorado Water Conservation Board (CWCB) with the responsibility of conserving the state's water resources. In part, the legislation requires the CWCB to provide loans to "construct, rehabilitate, enlarge, or improve flood control, water supply, and hydropower facilities" (COLO. REV. STAT. § 37-60-119[1][a][1971]). In response, the CWCB implemented the Water Project Loan Program with a starting program reserve of $\$ 10$ million (Mauss 2017). Today, the program provides low-interest loans to agricultural, municipal, and commercial borrowers for the design and construction of raw water projects, including hydropower projects (CWCB 2017).

The CWCB Construction Fund and Colorado's Severance Tax Trust Fund provide revenue for the Program (CWCB 2016). The Construction Fund is the state's largest revolving loan program financing water diversion and storage projects (COLO. REV. STAT. §§37-60-121 et seq. [2003]). Colorado law mandates that the Construction Fund must prioritize money for projects that increase the "beneficial consumptive use of Colorado's undeveloped compact entitled waters," which includes hydropower development (COLO. REV. STAT. §§37-60-121 et seq. [2003]). To utilize the Construction Fund for loans for more than $\$ 10$ million, the CWCB must obtain the Colorado General Assembly's approval (Colo. Leg. Council 2016). The Severance Tax Trust Fund generates money through taxes imposed on the production or extraction of metallic minerals, molybdenum, oil and gas, oil shale, and coal. Colorado law allocates $50 \%$ of the funds generated from the severance tax to the CWCB for state water projects (COLO. REV. STAT. § 3929-109[2][a] [2001]).

The Water Project Loan Program provides 2\% interest 30-year loans with a 1\% loan service fee. A loan feasibility study is required for any funding request from the CWCB. The loan feasibility study must outline the need for the project; the technical, economic, institutional, and financial 
feasibility of the project; and the potential social and environmental impacts of the project. The feasibility study must also provide a detailed description and analysis of the water supply source and existing and future water right demands (CWCB 2016). The program does not provide funding to private developers or for any on-farm hydropower project. In addition, the CWCB does not typically provide loans for less than $\$ 100,000$ (Mauss 2017).

As of mid-2017, the program has approximately $\$ 1$ billion in equity, providing loan funding to five hydropower projects totaling $22 \mathrm{MW}$. For example, in 2016 the CWCB awarded a loan to the Southeastern Colorado Water Conservancy District (SCWCD) for \$17,392,200 at 2\% interest financing with a $1 \%$ loan service fee for 30 years. SCWCD is using the loan funding to construct a 7.5 MW hydropower facility that utilized the existing outflows from the Pueblo Dam on the Arkansas River. Once commissioned, the Pueblo Dam Hydropower Project would generate on average generate $28,000 \mathrm{MWh}$ annually and \$1,500,000 in average revenue per year (CWCB 2016a).

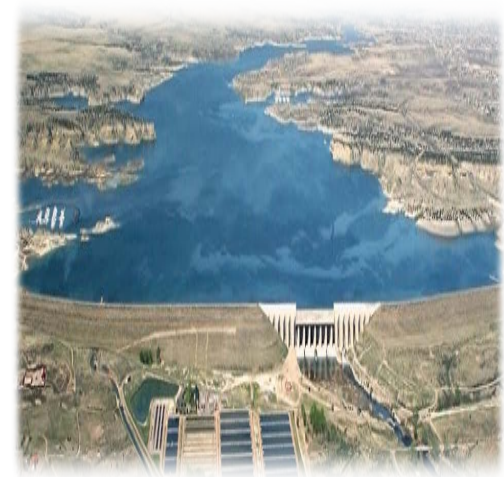

Figure 1. Southeastern Colorado Water Conservancy District - 7.5 MW Pueblo Dam Project. Photo courtesy of the CWCB

Similarly, in 2014, the CWCB provided a loan to the Northern Colorado Water Conservation District (NCWCD) for $\$ 5,669,340$ at $2 \%$ interest financing with a $1 \%$ loan service fee for 30 years. NCWCD used the loan to construct a $1.2 \mathrm{MW}$ hydropower project on the existing Granby Dam. NCWCD designed the Granby Hydropower Project to generate between 480 to $500 \mathrm{MWh}$ per year with electricity revenues projected to be approximately $\$ 390,000$ annually (CWCB 2014).

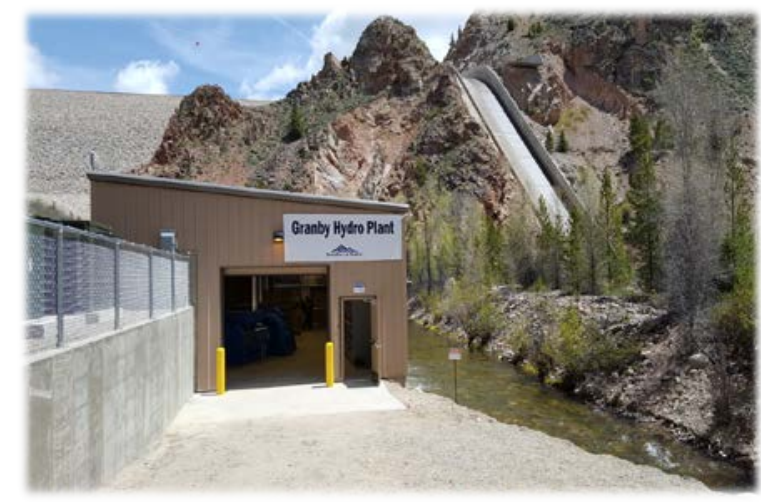

Figure 2. Northern Colorado Conservation District - 1.2 MW Granby Dam Project. Photo courtesy of the CWCB 


\subsubsection{Advantages}

Potential advantages associated with the CWCB's Water Power Loan Program include:

- Access to low-interest loans providing capital necessary to develop small hydropower projects in Colorado

- More favorable and more flexible loan terms than traditional lending institutions

- A straightforward and easy-to-navigate loan application process

- No up-front financing requirements

- No maximum loan amount

- A revolving revenue stream.

\subsubsection{Challenges}

Potential challenges associated with the CWCB's Water Power Loan Program include:

- Loan revenue fluctuations based on funding restrictions or other water resource priorities (e.g., flood events)

- Loans greater than $\$ 10$ million must gain approval from the Colorado General Assembly

- Funding restrictions on private developers and any on-farm hydropower project

- The practice of obtaining the first $\$ 2$ million of funding from the Colorado Water Resource Power Department Authority before obtaining additional funding from the CWCB

- The CWCB's reluctance to provide loans for less than $\$ 100,000$.

\subsubsection{Oregon: Small Scale Energy Loan Program}

\subsubsection{Implementation History and Process}

In 1979, the Oregon Legislative Assembly created the ODOE's Small Scale Energy Loan Program (SELP) to encourage the development of local renewable energy (OR. REV. STAT. §§ 470 et seq. [1979]). Prompted by a 1975 study evaluating the state's energy resource potential and growing environmental concerns, the Legislature enacted SELP to provide long-term, lowinterest loans for renewable energy projects, including small-scale hydropower (ODOE 2014; OR. ADMIN. R. §§ 330-110-0005 et seq. [2013]).

In 1979, ODOE recognized that the primary impediment to widespread use of existing renewable energy technology was the high capital cost of construction and installation. According to ODOE research, low-cost loans were one of the most effective incentives to develop renewable energy resources (City Club of Portland 1980). In furtherance of SELP, voters approved a constitutional amendment to Article XI-J in a 1980 special election authorizing the state to sell bonds, backed by state credit, up to $0.5 \%$ of the value of taxable property in Oregon, to create the SELP revolving loan fund (City Club of Portland 1980; ODOE 2014). 
SELP remains a revolving loan fund that derives revenue from interest margins, loan fees, reimbursed expenses, and loan payments received on outstanding obligations. The full faith and credit of the State of Oregon protects the SELP loan fund, requiring the State General Fund to support the SELP fund in the event of revenue shortfall (Connolly 2016). ODOE loans money to individuals, businesses, schools, state and local governments, tribes, public cooperatives, and nonprofit entities through SELP (OR. REV. STAT. § 470.060 [1979]). ODOE provides SELP funds to small- and large-scale hydropower projects on a case-by-case basis.

SELP provided its first loan in 1981. From 1981 to 2000, ODOE approved more than 530 loans. During this time, 29 of the 530 loans were for hydropower development. Historically, SELP has served as a "significant funding resource for local irrigation districts' small-scale hydropower projects" (OR. REV. STAT. § 470.060 [1979]). However, ODOE has awarded the majority of contemporary SELP loans to non-hydropower renewable projects. As of June 2016, ODOE had issued more than 900 loans totaling $\$ 610$ million. A minority of these loans were for hydropower development, and an even smaller number was for small-scale hydropower development (ODOE 2016; Hobbs 2017).

\subsubsection{Advantages}

A 2002 National Renewable Energy Laboratory report found that stakeholders interviewed considered SELP "a major driver in the development of some large commercial/industrial renewable energy projects - primarily hydropower and biomass - but agreed that it may be less effective at stimulating residential-scale projects despite the fact that most renewable energy projects are relatively small." In addition, the report found SELP provided a high level of available funding and loan flexibility due to the convenient, in-house structure provided by the ODOE. Other advantages to SELP include the ability of applicants to bundle energy efficiency improvements with the installation of renewable energy technologies (Gouchoe 2002).

\subsubsection{Challenges}

As noted in a legislative report in 1980 considering SELP's implementation, "improper administration, unexpected defaults, or subsequent changes...could result in taxpayer liability. If loan defaults result in the [SELP fund] being inadequate to repay the bonds as they come due, the state is required to retire the bonds from the General Fund. If adequate sums are not otherwise available to the state, statewide property taxes will be levied." The initial 1980 legislative report also noted that if the state issued too many bonds, the state's bond rating could suffer, raising the interest rate on state bonds and increasing the cost of state borrowing (City Club of Portland 1980).

In 2012, due to defaults of large loans made through SELP, Oregon Treasurer Ted Wheeler recommended that the state augment SELP's depleted loan-loss revenue to safeguard the state against future potential defaults. Instead, SELP continued without replenished reserves. Since 2012, additional large loans have fallen into default (Oregon State Treasury 2016).

In recent years, SELP has faced continued financial uncertainty. In December 2015, Governor Kate Brown announced a comprehensive review of SELP and ODOE. Subsequently, the State Legislature formed a special committee to examine ODOE's responsibilities and oversight of SELP. For the fiscal year ending in June 30, 2015, SELP reported a negative fund balance of approximately $\$ 20$ million. In January 2016, State Treasurer Wheeler made a recommendation to 
Governor Brown to suspend SELP loans after he found that starting in 2019 SELP would require cash infusions continuing through 2034 to meet scheduled debt service obligations. The ODOE, State Treasurer, and the Oregon Department of Administrative Services forecast a \$15.3 million shortfall. The actual shortfall could change depending on additional delinquencies and ODOE's success at pursuing repayments and assets (Brown 2016; Connolly 2016).

Most recently, a 2017 Legislative Fiscal Office Budget Information Report found that due to "significant loan defaults, the [SELP] fund is in a deficit position and is not forecasted to be selfsustaining" (Oregon Legislative Fiscal Office 2017). The report went on to say that the state's general fund would "likely be required to meet debt service obligations" (Oregon Legislative Fiscal Office 2017). Governor Brown's 2017 budget requested funds to move SELP from ODOE to the Oregon Department of Business (ODOB) (Oregon Department of Administrative Services 2016). Current proposed legislation, House Bill 2756, proposes to transfer the duties, functions, and powers of the ODOE related to issuance of SELP loans to ODOB (OR. H.B. 2756, 79 ${ }^{\text {th }}$ OR. LEG. ASS. [2017]).

\subsection{Grant Model}

States offer a variety of grant programs designed to foster renewable energy development. Most grant models propose to pay down the cost of equipment or systems, while other grant models encourage research or development of renewable technologies, or aid for commercialization. Most grant programs are available for a range of renewable sources, while other designs support an individual technology (Doris 2009). States such as Colorado and Massachusetts have developed grant programs to encourage small hydropower development.

\subsubsection{Colorado: Regional Conservation Partnership Program Pressurized Irrigation Small Hydropower Partnership Project (RCPP Irrigation Hydropower Program)}

\subsubsection{Implementation History and Process}

In 2015, the Colorado Department of Agriculture (CDA) entered into an agreement with the U.S. Department of Agriculture (USDA) to provide \$2.9 million in financial and technical assistance for agricultural hydropower development. The partnership agreement, known as the RCPP 38 Pressurized Irrigation Small Hydropower Partnership Project (RCPP Irrigation Hydropower Program), provides grant funding to Colorado agricultural producers to install small net-metered hydropower projects (up to $100 \mathrm{~kW}$ ) at new and existing irrigation systems (Anderson 2017).

Funding for the RCPP Irrigation Hydropower Program comes from USDA's Regional Conservation Partnership Program (RCPP), USDA's Rural Energy for America Program (REAP), and the CDA's Advancing Colorado's Renewable Energy and Efficiency (ACRE ${ }^{3}$ ) grant program (Anderson 2017). As part of the RCPP Irrigation Hydropower Program, the CDA developed an agricultural hydropower technical manual that outlines the project development process, and trained 70 engineers around the state as agricultural irrigation hydropower technical

\footnotetext{
${ }^{38}$ RCPP was created by the 2014 Farm Bill to promote coordination between USDA's Natural Resources Conservation Service and funded RCPP projects are implemented through RCPP contracts and easement agreements under the Agricultural Conservation Easement Program, EQIP, Conservation Stewardship Program, or the Healthy Forests Reserve Program.
} 
service providers. ${ }^{39}$ The CDA's ACRE 3 program also coordinates projects for the RCPP Irrigation Hydropower Program by soliciting pre-applications and providing technical and financial assistance for hydropower resource assessments and feasibility studies. Pre-applications that meet minimum feasibility criteria may then apply for funding from the CDA's $\mathrm{ACRE}^{3}$ grant program, the USDA's Environmental Quality Incentives Program (EQIP), and the USDA's REAP. Successful applicants may receive contracts from each of these programs, providing assistance that may include engineering and other technical services from the USDA's Natural Resources Conservation Service (NRCS) and the CDA, and funding for equipment and installation costs.

The USDA's RCPP has dedicated nearly \$1.5 million within EQIP for the RCPP Irrigation Hydropower Program. EQIP provides financial and technical assistance, up to $\$ 450,000$ for 10 years, to eligible agricultural producers to plan and implement conservation practices. The USDA has also committed up to $\$ 440,000$ in REAP funds for the RCPP Irrigation Hydropower Program. The USDA may provide REAP grants for up to $25 \%$ or loans and grant-loan combinations up to $75 \%$ for qualifying equipment and installation costs. The USDA's NRCS provides EQIP and REAP funding on a reimbursement basis once NRCS certifies the project. Typically, REAP grants cannot be combined with EQIP financial assistance, but the RCPP Irrigation Hydropower Program received a special waiver on this rule from the USDA (Anderson 2017).

The CDA's $\mathrm{ACRE}^{3}$ grant program has dedicated approximately $\$ 1.6$ million for the RCPP Irrigation Hydropower Program. The CDA may award $\mathrm{ACRE}^{3}$ funds to eligible projects for up to $25 \%$ of eligible project cost, not to exceed $\$ 25,000$ per project. Eligible project costs for $\mathrm{ACRE}^{3}$ funding include certain engineering, equipment, and installation costs for hydro-turbine and power generation equipment, grid interconnection equipment, powerhouse, and balance-ofsystem components. The CDA approves funding for feasibility assessments, penstocks/pipelines, and irrigation equipment separately from other eligible projects on a case-by case basis. Projects approved for EQIP hydropower funding automatically qualify for $\mathrm{ACRE}^{3}$ funding. The CDA provides $\mathrm{ACRE}^{3}$ funding on a reimbursement basis at project completion. $\mathrm{ACRE}^{3}$ also provides grants up to $\$ 25,000$, outside of the RCPP Irrigation Hydropower Program, for the development of small hydropower projects in irrigation canal drops and small reservoirs (5 MW or less) (Anderson 2017).

As of June 2017, the RCPP Irrigation Hydropower Program has funded two hydropower projects, which received combined funding of $\$ 20,968$ from $\mathrm{ACRE}^{3}, \$ 28,100$ from EQIP, and $\$ 27,000$ from REAP. For example, in 2015 the Park Family Farm received \$9,568 in ACRE ${ }^{3}$ funding to install $10-\mathrm{kW}$ hydroelectric turbines that power two center-pivot irrigation systems on 125 acres of land in Kersey, Colorado. Susan Raymond also received \$11,400 in ACRE $^{3}$ funding to install hydroelectric turbines generating $8 \mathrm{~kW}$ of power to run three center pivots on 37 acres of land and to provide electricity for an on-site veterinary practice in Hotchkiss, Colorado. The RCPP Irrigation Hydropower Program, through the CDA's ACRE ${ }^{3}$, has also completed

\footnotetext{
${ }^{39}$ Technical Service Providers (TSPs) are USDA NRCS-certified conservation experts that provide technical assistance (e.g., plan, design, layout, review of conservation practices) for EQIP incentive programs. A TSP must be used to receive technical assistance and certain financial assistance through EQIP-funded projects. Before 2015 there was a limited amount of TSPs in Colorado and in the surrounding states that had technical expertise in developing hydropower projects at agriculture irrigation systems.
} 
feasibility studies for 36 proposed hydropower projects ( $100 \mathrm{~kW}$ or less) and hopes to provide funding to 12 new projects by April 2018 (Anderson 2017).

\subsubsection{Advantages}

Potential advantages associated with the RCPP Irrigation Hydropower Program include:

- Additional financial benefit to agricultural producers associated with capturing existing water to generate electricity at irrigation infrastructures

- Increased energy efficiency associated with upgrading aging irrigation infrastructure

- Labor cost reductions associated with converting flood irrigation to sprinkler irrigation

- Small hydropower development opportunity at gravity-fed irrigation systems around the state totaling $30 \mathrm{MW}$ of potential energy

- Ancillary benefits (e.g., positive impacts on local economy, the watershed community, water-use efficiency, and watershed health) and increased funding opportunities associated with coupling agricultural infrastructure improvements with power generation

- Broader public support based on the environmental and local economy benefits

- Grant funding that requires no repayment.

\subsubsection{Challenges}

Potential challenges associated with the RCPP Irrigation Hydropower Program include:

- The complexity and time associated with the application and reward process

- Coordination challenges between the CDA and the USDA regarding funding and technical assistance requests

- Potential fluctuations in grant revenue/financing

- Delays between funding announcements

- Up-front cost requirements and payment only through reimbursement

- Availability of technical service providers required for EQIP funded projects.

\subsubsection{Massachusetts: Commonwealth Hydropower Program}

\subsubsection{Implementation History and Process}

In 1997, the Commonwealth of Massachusetts passed an electric-utility restructuring law, the Electric Industry Restructuring Act (Restructuring Act), to introduce elements of competition in Massachusetts' retail electric market. To address concerns that the new law would discourage utility investment in energy efficiency and renewable energy, the Restructuring Act created a Renewable Energy Trust Fund (RE Fund). The Restructuring Act mandated that the RE Fund support hydropower, solar, wind, ocean, landfill gas, biomass, and energy efficiency measures (Mass. Tech. Collaborative 2008). To generate revenue for the RE Fund, the law required that investor-owned utilities and competitive municipal utilities implement a $\$ .0005$ per kWh surcharge on customer electric bills (1997 Mass. Acts Ch. 164). 
In 2008, the Massachusetts Legislature passed the Green Jobs Act, which revised the RE Fund to encourage the statewide adoption of renewable energy, including hydropower development. The Green Jobs Act created the Massachusetts Clean Energy Center (MassCEC), a publicly funded agency tasked with promoting renewable energy development, jobs, and education. The Green Jobs Act also created the Massachusetts Alternative and Clean Energy Investment Fund (ACEIT Fund) to support MassCEC activities (2008 Mass. Acts Ch. 307 (codified in MASS. GEN. LAWS CH. 23J, § 2 [2008]). In 2009, the Legislature passed the Clean Energy Act which, in part, merged the RE Fund and the ACEIT Fund and the 1997 and 2008 legislative directives. The Clean Energy Act also mandated that MassCEC manage the merged RE Fund and create a hydropower program (2009 Mass. Acts Ch.158).

MassCEC manages the RE Fund and, as directed by the Clean Energy Act, created the Commonwealth Hydropower Program. The objective of the Commonwealth Hydropower Program is to increase the output of the Commonwealth's hydropower assets. The Commonwealth Hydropower Program provides grants for construction projects and feasibility studies for eligible hydropower facilities, which include FERC licensed or non-jurisdictional ${ }^{40}$ facilities seeking efficiency upgrades, new FERC qualifying conduit facilities, and new $30 \mathrm{MW}$ or less FERC conduit facilities (MassCEC 2016). The Commonwealth Hydropower Program also provides grant funding for the design and construction of facility modifications. Eligible hydropower projects must also demonstrate a high probability of qualifying for Massachusetts' RPS, which generally requires certification by the Low Impact Hydropower Institute ${ }^{41}$ (Barad 2017).

MassCEC construction grants for hydropower facilities can be up to $50 \%$ of the allowable project costs (up to $\$ 175,000$ ), which is currently set at $\$ 1.20$ per incremental $\mathrm{kWh}$ per year. For example, MassCEC would cap a grant for a project that costs $\$ 1$ million and increases a facility's output by $250,000 \mathrm{kWh}$ at $\$ 300,000$. MassCEC caps grants for feasibility studies at $\$ 45,000$, subject to a formula and cost-share requirements. MassCEC accepts applications until program funding runs out. For fiscal year 2017, MassCEC has approximately \$1.2 million to provide grants for construction and feasibility studies for eligible hydropower facilities. As of June 2017, MassCEC has funded 13 small hydropower projects. Of these 13 projects, nine are operational, producing a total of 5,211 MWh annually. The remaining four projects are not yet operational but are expected to produce a total of 2,257 MWh per year (MassCEC 2016).

MassCEC provides funding to construct automated controls for more efficient operation, new turbines better suited for run-of-river operations, and automated trash rakes that keep intakes clear of ice and debris that can block water flow (Barad 2017). For example, in 2013 MassCEC awarded Littleville Power a grant of $\$ 600,000$ for the addition of a new minimum-flow turbine at the Glendale Dam in Stockbridge, Massachusetts. The project was completed in 2015. The grant leveraged over \$2 million in private funds, and the turbine has produced 1,000 MWh annually.

\footnotetext{
${ }^{40}$ Non-jurisdictional facilities are those that do not require FERC authorization. Very few facilities are not subject to FERC jurisdiction. Typically, non-jurisdictional facilities are only those that have been in continuous operation since 1935 and whose capacity has not been increased since that time.

${ }^{41} 225$ CODE OF MASS. REG. 14.05(1)(a) (Massachusetts' RPS requires retail electricity suppliers to provide $15 \%$ of Class I renewables by 2020 and an additional 1\% thereafter. Hydroelectric plants in class one are limited to facilities $30 \mathrm{MW}$ or less.)
} 
Over an assumed 30-year project life, MassCEC's contribution amounts to 2 cents per incremental kWh. (Barad 2017).

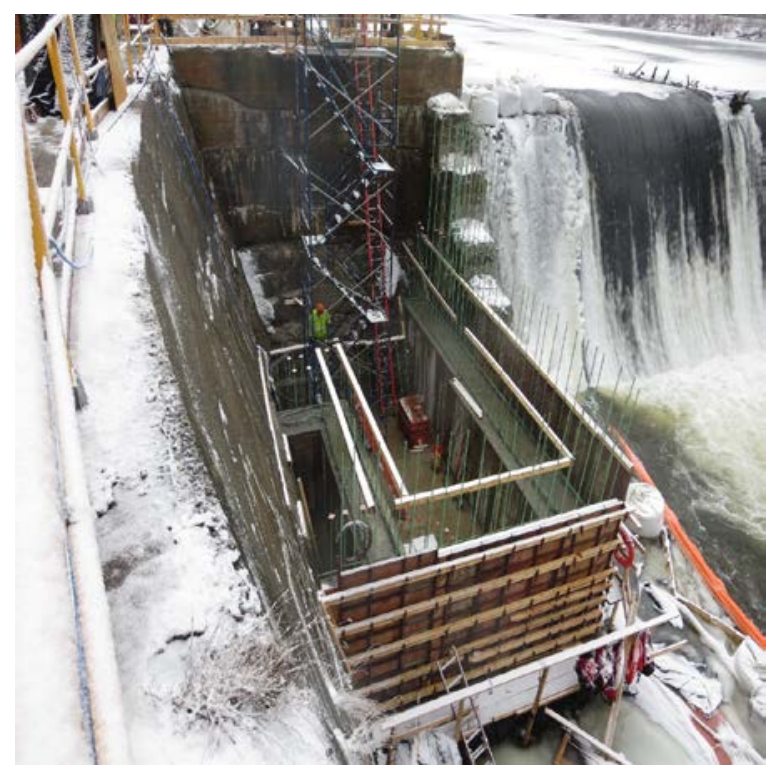

Figure 3. Glendale Dam Project - Minimum Flow Turbine Replacement. Photo courtesy of the MassCEC

In 2015, MassCEC also awarded Mini-Watt Hydroelectric a grant of $\$ 500,000$ to make a number of upgrades and repairs on the 1940 's-era facility with a nameplate capacity of $455 \mathrm{~kW}$. Some of the project upgrades included replacing a turbine runner, repairing the seals on the dam's crest gate, addressing leaks in the overspill, and updating the facility's control. Taken together, these improvements are expected to increase average generation by $766 \mathrm{MWh}$ per year. Over an assumed 30-year project life, MassCEC's contribution amounts to 2.2 cents per incremental $\mathrm{kWh}$. (Barad 2017).

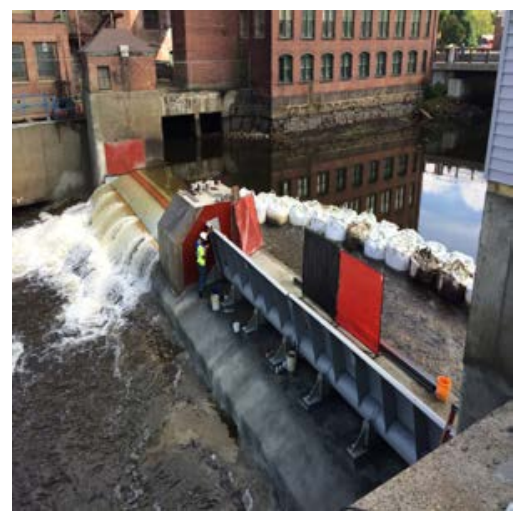

Figure 4. Mini-Watt Hydroelectric - $455 \mathrm{~kW}$ Project. Photo courtesy of the MassCEC

\subsubsection{Advantages}

MassCEC grants provide capital to develop small-scale hydroelectric projects that would otherwise not be available. These grants provide a direct cash incentive to support hydropower development. Unlike loan programs, the grant incentive provided by MassCEC does not require repayment. 


\subsubsection{Challenges}

Grant funding is limited. Generating revenue for the fund may be difficult to sustain long-term. In addition, electric customers may not always support a surcharge to be used for MassCEC programming. 


\subsection{Hybrid Grant-Loan Model}

Some states, including Colorado, have created low-interest loan programs combined with grant incentives to promote small hydropower development.

\subsubsection{Colorado: Small Hydropower Loan Program with Matching Grant Availability}

\subsubsection{Implementation History and Process}

In 1981, the Colorado Legislature created the Colorado Water Resources and Power Development Authority (CWRPDA) to assist in the management and development of water resources for the state. ${ }^{42}$ In part, the legislation requires the CWRPDA to finance state government water management and hydropower projects. In 2008, the CWRPDA created the Small Hydropower Loan Program that went into effect in 2009 with a starting program reserve of $\$ 10$ million (Colorado Leg. Council 2016). Utilizing the CWRPDA's unrestricted cash funds, the Program provides low-interest loans to local Colorado governments ${ }^{43}$ for small hydropower development.

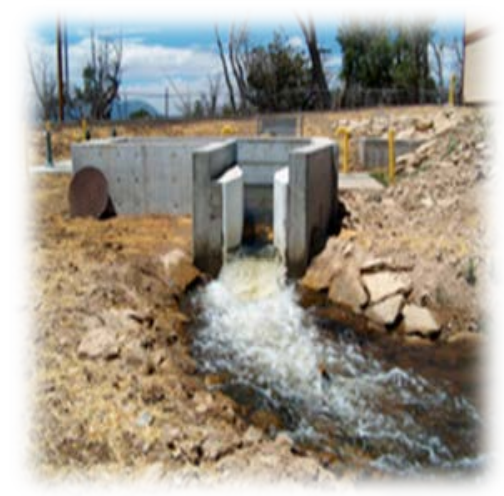

Figure 5. City of Cortez - 240 kW Water Treatment Plant Project. Photo courtesy of CWRPDA

Initially, the program provided $2 \%$ interest 20 -year loans, up to $\$ 2$ million to local governments developing hydropower facilities less than $5 \mathrm{MW}$. Today, the program provides $2 \%$ interest 30 year loans, up to $\$ 5$ million to local governments for the development of FERC-exempt hydropower facilities up to $10 \mathrm{MW}$. Local governments may also use the loan for feasibility studies, engineering, permitting, and related ancillary costs (e.g., pipelines and transmission lines). The CWRPDA structures annual loan repayments to begin 12-18 months from the loan agreement date and there is no upfront financing required (CWRPDA 2017).

\footnotetext{
${ }^{42}$ COLO. REV. STAT. § 37-97-104(3) (1796) (provision originally enacted in 1796 directing development of CWRPDA to commence in 1981).

${ }^{43}$ Local governments include Colorado cities, towns, counties, water districts, water and sanitation districts, metropolitan districts, water conservancy districts, water conservation districts, irrigation districts, and any enterprise created by the above entities.
} 


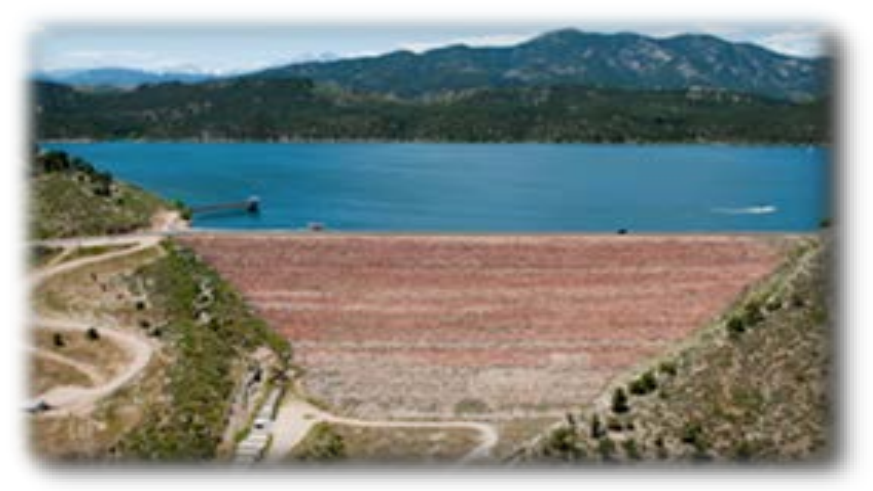

Figure 6. Northern Colorado Water Conservancy District - 1.3 MW Carter Lake Reservoir Project. Photo courtesy of CWRPDA

The CWRPDA has also authorized $\$ 150,000$ of matching grant funds for feasibility studies, permitting, and final design activities of small hydropower projects (10 MW or less). The program restricts matching grant availability to $\$ 15,000$ with a $50 \%$ match for each local government. In addition, the CWRPDA and the CWCB operate in partnership to jointly fund small hydropower facilities. Local government entities seeking funding in excess of $\$ 5$ million may obtain more funding through CWCB's Water Project Loan Program (CWRPDA 2017; Colo. Leg. Council 2016). As of mid-2017, the CWRPDA has provided $\$ 7.5$ million in loan funding to five hydropower projects totaling $9 \mathrm{MW}$. In addition, the CWRPDA has provided feasibility grants to 40 projects totaling $\$ 530,000$ (Williams 2017).

In 2009, the City of Cortez in Colorado received a \$1.5 million loan through the CWRPDA's Small Hydropower Loan Program to retrofit the city's water treatment plant to include a $240 \mathrm{~kW}$ hydropower generator. The City of Cortez project produces 1 million $\mathrm{kWh}$ of hydropower annually generating $\$ 115,000$ in revenue per year (Williams 2017).

Similarly, in 2011 the Northern Colorado Water Conservancy District received a \$1.5 million the CWRPDA loan for a 1.3 MW hydropower project on the Carter Lake Reservoir in Colorado. The project also received a $\$ 15,000$ matching grant from the CWRPDA for a feasibility study. The 1.3 MW hydropower project, constructed in 2012, produces 7-8 million $\mathrm{kWh}$ of hydropower annually generating $\$ 600,000$ in revenue per year (Williams 2017).

\subsubsection{Advantages}

Potential advantages associated with the CWRPDA Small Hydropower Loan Program include:

- Access to low-interest loans necessary to develop small hydropower projects in Colorado

- More favorable and more flexible loan terms than traditional lending institutions

- A straight-forward and easy to navigate loan application process

- No up-front financing requirements.

\subsubsection{Challenges}

Potential challenges associated with the CWRPDA Small Hydropower Loan Program include: 
- Loan revenue fluctuations based on funding restrictions or other water resource priorities

- The $\$ 2$ million loan cap

- Funding restrictions limiting loan eligibility to local government entities.

\subsection{Feed-in-Tariff Model}

Feed-in-tariffs (FITs) are legislatively mandated, technology-based wholesale rates that electric utilities pay to small-scale producers of renewable electricity. FITs promote renewable energy by providing for the cost of production and a small profit (Stokes 2009). States like Rhode Island and Vermont have adopted a FIT model to incentivize the development of local small hydroelectric power.

\subsubsection{Rhode Island: Renewable Energy Growth Program}

\subsubsection{Implementation History and Process}

In 2014, the Rhode Island General Assembly passed Act H. 7727, creating the Renewable Energy Growth Program (REG Program) to encourage the development of local renewable distributed generation (DG) (R.I. GEN. LAWS §§ 39-31-1[1]-[5] [2014]). Recognizing the state's renewable energy resource potential, which includes development of 10 to $20 \mathrm{MW}$ of small hydropower at existing dams, the REG Program aligns with the state's energy plan to diversify Rhode Island's energy portfolio, creating jobs and grid reliability (Rhode Island Dep't. of Admin. 2015).

In order to supplement Rhode Island's Renewable Energy Standard (RES) ${ }^{44}$ the General Assembly passed a series of laws creating financing mechanisms to attract investors, stabilize the market, and help developers overcome prohibitive capital costs. Unlike the RES, which requires electricity providers to purchase RECs, these procurement laws require Rhode Island's primary electric distribution company, National Grid, to enter into long-term power purchase agreements with renewable energy generators for both RECs and power (Rhode Island Dep't. of Admin. 2015).

The first of these laws, enacted in 2009, was the Long-Term Contracting Standard for Renewable Energy (LTC). The LTC required electric distribution companies to annually solicit proposals from renewable energy developers and to enter into long-term contracts, with terms up to 15 years, for $90 \mathrm{MW}$ of renewable capacity by December 2014 (R.I. GEN. LAWS §39-26.1 [2009]). By 2011, there was a growing recognition that the LTC was not adequately supporting development of small renewable energy projects in the state (Rhode Island Dep't. of Admin. 2015). In response, the General Assembly passed a host of new laws encouraging the expansion of in-state renewable energy generating capacity, including the landmark renewable energy procurement provision establishing Distributed Generation Standard Contacts (DGSC) (R.I. GEN. LAWS §39-26.2 [2011]). This law set forth minimum capacity targets for electric distribution companies to purchase RECs and power from renewable energy projects located in their load zone, ramping to $40 \mathrm{MW}$ of nameplate capacity by the end of 2014 (Rhode Island Dep't. of Admin. 2015). As of the end of 2014, the DGSC Program had awarded 37 MWs of capacity to

\footnotetext{
${ }^{44}$ R.I. GEN. LAWS $\S 39-26$ et seq. (2004) (requiring electric distribution companies and non-regulated power producers to supply 16 percent of power sold to end users in Rhode Island from renewable energy resources by 2019).
} 
Rhode Island-based wind, solar, and anaerobic digestion projects (Rhode Island Off. of Ener. Res. 2014). The DGSC Program did not award contracts to any hydropower projects. The successes of the DGSC Program ultimately led to the consideration and passage of the REG Program (Rhode Island Dep't. of Admin. 2015).

Replacing the DGSC Program, the REG Program provides tariff-based, renewable-energy DG financing (R.I. GEN. LAWS \$39-26.6-2 [2014]). Expanding the goal of the DSGC Program, the REG Program calls for 200 MW of local renewable energy by 2019 (Rhode Island Dep't. of Admin. 2015). The REG Program provides financing for the development, construction, and operation of renewable DG generation facilities over five years through a performance-based incentive system. Eligible renewable DG facilities include "electric-generation facilities located in the electric-distribution company's load zone with a nameplate capacity no greater than 5 MWs, using eligible renewable resources." Eligible renewable resources include "small hydroelectric, direct solar radiation, wind, geothermal, biomass, hydrokinetic, and fuel cell facilities not greater than $5 \mathrm{MWs"} \mathrm{(R.I.} \mathrm{GEN.} \mathrm{LAWs} \S \S 39-26$ et seq. [2004]). The term lengths for the incentive vary by project type and size from 15 to 20 years. For small-scale hydropower projects with $10-1,000 \mathrm{~kW}$ the ceiling price, including bonus depreciation, is $22.65 \mathrm{cents} / \mathrm{kWh}$ for 20-year terms of service (National Grid 2017).

National Grid has the responsibility of implementing the REG Program under the supervision and review of the Rhode Island Public Utility Commission (RIPUC). For a period of at least five years, National Grid must file tariffs with the RIPUC designed to provide multi-year performance-based incentives to eligible renewable DG projects (R.I. GEN. LAWS §§39-26 et seq. [2004]). RIPUC reviews and approves the tariffs developed by National Grid. Proposed tariffs must include a ceiling price and term lengths for 15 to 20 years. If approved by RIPUC, the terms under the tariffs are not altered in any way that would undermine reliance on those tariffs (DOE 2017a). The REG Program is expected to create approximately 250 in-state jobs and increase state tax revenue by over $\$ 1$ million a year (DOE 2017a).

As of mid-2017, the REG Program has supported 65 local renewable energy projects totaling approximately $57 \mathrm{MW}$ of capacity located in 20 municipalities across Rhode Island (Rhode Island Senate Policy Office 2016). The REG Program has not supported any small hydropower projects and the majority of the financing has been for medium, large, and commercial solar.

\subsubsection{Advantages}

Potential advantages associated with Rhode Island's REG Program include:

- Predictable return on investment for developers and investors

- Relatively stable revenue fund generated from electric rate tariffs

- A simple, streamlined application process.

\subsubsection{Challenges}

Potential challenges associated with Rhode Island's REG Program include:

- No utilization by hydropower developers due to lack of viable site locations 
- The complexity of setting tariff rates so they properly incentivize development.

\subsubsection{Vermont: Standard Offer Program}

\subsubsection{Implementation History and Process}

In 2009, the Vermont General Assembly enacted legislation, H.466, to encourage the development of small-scale local renewable energy. Recognizing the success of FITs in Europe, the legislature promulgated the Vermont Energy Act (Act 45), providing a reasonable return on investment to renewable energy developers. ${ }^{45}$ Act 45 modified Vermont's Sustainably Priced Energy Enterprise Development (SPEED) Program creating the Standard Offer Program, one of the nation's first FITs (Taylor 2009, Douglas 2009). The Vermont General Assembly enacted the SPEED Program to encourage the development of renewable energy resources in Vermont, as well as the purchase of renewable power by the state's electric distribution utilities (30 VT. STAT. ANN $\S \S 8001$ et seq. [2005]).

The Standard Offer Program requires all Vermont retail electricity providers to purchase electricity generated by eligible renewable energy facilities through long-term contracts with fixed standard offer rates. Eligible renewable energy facilities include small hydropower facilities up to $2.2 \mathrm{MW}$ along with new solar, wind, biomass, landfill gas, and farm methane derived from agricultural operations and energy crops (30 VT. STAT. ANN. § 8005a(b); 16 U.S.C. $\S 796[17][\mathrm{C}])$.

Act 45 required the Vermont Public Service Board - recently renamed the Vermont Public Utility Commission (VPUC) - to establish cost-based prices for renewable energy facilities with a nameplate capacity of $2.2 \mathrm{MW}$ or less (30 VT. STAT. ANN $\S 8005 \mathrm{a}$ [c][2]). The VPUC initially established cost-based pricing on a calculated avoided cost basis for eligible renewable energy projects. ${ }^{46}$ In 2012, the Vermont Legislature passed Public Act 170, which in part, increased the Standard Offer Program ceiling cap from $50 \mathrm{MW}$ to $127.5 \mathrm{MW} .{ }^{47}$ Act 170 also mandated the use of a market-based mechanism to determine pricing for Standard Offer Projects. In March, 2013, the VPUC established, pursuant to Section 8005a(f)(1), a request for proposal (RFP) marketbased mechanism to determine the standard-offer projects that fill annual plant capacity available under the Standard Offer Program (Vt. Pub. Serv. Brd. 2013). The VPUC directed the Standard Offer Facilitator ${ }^{48}$ to issue an RFP to solicit standard-offer projects to meet the requirements of section $8005 \mathrm{a}(\mathrm{c})$. The VPUC also established technology-specific avoided costs to serve as caps on the standard-offer prices solicited through the RFP (Vt. Pub. Serv. Brd. 2013). The 2017 RFP allows an avoided cost for new small hydropower facilities (2.2 MW or less) up to $\$ 0.130$ per kWh, fixed over the term of a 20 years contract (Vt. Pub. Serv. Brd. 2017).

\footnotetext{
452009 Vt. Acts \& Resolves 324025 (codified at Vt. Stat. Ann. Tit. $30 \S 8005$ [b][2008]), amended by Vermont Energy Act of 2012, 2012 Vt. Acts \& Resolves 170 (codified at Vt. Stat. Ann. Tit. 30, §8005a [Supp. 2015])(allowing eligible projects of $2.2 \mathrm{MW}$ or less to participate in the feed-in-tariff).

4630 VT. STAT. ANN. $\$ 8005$ (b)(7)(Prior to the 2012 legislation the SPEED Facilitator, VEPP Inc., a nonprofit acting as the purchasing agent, distributed the energy and attendant costs to the Vermont distribution utilities based on each utility's pro rata share of total Vermont retail $\mathrm{kWh}$ sales for the previous calendar year.)

${ }^{47}$ Vermont Public Act 170, 2012 Vt. Acts \& Resolves 727(codified at Vt. Stat. Ann. Tit. 30, §8005a [Supp.

2015])(allowing eligible projects of 2.2 MW or less to participate in the feed-in-tariff).

${ }^{48}$ VEPP Inc., serves as the Standard-Offer Facilitator under contract with the VPUC.
} 
As of mid-2017, four hydropower projects, totaling 4.9 MW, have utilized Vermont's Standard Offer Program (Alderman 2017). Blue Heron Hydro LLC, has two long-term contracts through Vermont's Standard Offer Program for the Blue Heron Hydropower Project. The project consists of two facilities - a 2.2 MW plant on the Ball Mountain Dam in Jamaica, Vermont, and a 900 $\mathrm{kW}$ plant on the Townshend Dam in Townshend, Vermont. Both facilities are located at U.S. Army Corps of Engineers flood control dams on the West River in southern Vermont. Together, the two projects will produce over 10,000 MWh annually.

Similarly, the Great Bay Hydro Corporation has a long-term contract through Vermont's Standard Offer Program for the West Charleston Hydropower Project. The project is a redevelopment of a decommissioned hydropower facility located on the Clyde River in Charleston, Vermont. The $675 \mathrm{~kW}$ project produces approximately 3,000 MWh annually.

\subsubsection{Advantages}

A 2011 National Association of Regulatory Utility Commissioners' (NARUC) report found that some of the key of advantages of Vermont's Standard Offer Program include:

- "Project owners who receive Standard Offer contracts know exactly how much money they will receive over time.

- By offering different prices for different technologies, the Standard Offer Program is able to account for differences between technologies and support the commercialization of a range of technologies, not just the least expensive ones.

- By having the megawatt cap, the program avoids one of the disadvantages of some European feed-in-tariffs, which is creating a program with an unpredictable and uncapped cost for ratepayers" (NARUC 2011).

\subsubsection{Challenges}

In 2011, the NARUC report found that a key disadvantage of Vermont's Standard Offer Program is that setting the right price level for standard offer payments is difficult. The report found that the Standard Offer Program risks giving project developers more money than they actually need to develop eligible projects (NARUC 2011). In addition, the lack of viable site locations has limited hydropower development in Vermont (Rubin 2017). 


\section{Discussion}

This section summarizes the advantages and challenges of the state regulatory streamlining and permitting assistance initiatives, and state financial incentives for the development of small hydropower facilities discussed in the report.

\subsection{General Advantages and Challenges of Regulatory Streamlining and Permitting Assistance Initiatives}

Regulatory streamlining efforts can save time associated with state and federal permitting, ultimately lowering capital costs. Encouraging upfront communication and coordinated resource reviews ensures adequate consultation and that state agency conditions do not conflict with one another. Permitting assistance often provides informational resources that can lead to increased project development efficiencies. Funding provided for initial capital costs for permitting and feasibility studies increase the viability of small-scale hydropower project development. However, regulatory streamlining efforts and permitting assistance are often not enough to overcome development barriers unless coupled with financial incentives.

\subsection{General Advantages and Challenges of Loan and Loan Guarantee Models}

Advantages associated with state loan and loan guarantee models include:

- Terms and conditions that are often more favorable than traditional lending institutions

- A broader range of projects often qualify for financing when compared to traditional lending institutions

- Long-term, fixed rate loans and reduced consumer-transaction costs

- More favorable default terms than traditional lending institutions

- The funds disbursed can be reused or recycled multiple times - unlike a grant

- Loan models stimulate economic development resulting in direct investment

- State loan programs provide an opportunity to educate consumers about energy related issues (Lantz 2010).

However, studies have found that loan programs targeting renewable energy have not generally resulted in high levels of deployment. Low participation in loan programs often attributes to the limitation of loan programs (Lantz 2010). 


\subsection{General Advantages and Challenges of Grant Models}

Advantages associated with state grant models include:

- Direct cash incentives to support up-front capital costs

- Repayment is typically not required

- Flexible support based on changes in the market, because grant models do not require a long-term policy or financial commitment to a specific project (Doris 2009).

However, grants are usually a one-time distribution and do not recycle funds to support longterm revenue. In addition, developing a grant program that provides sufficient funding to successfully incentivize development without providing excess funding is a difficult balance to achieve.

\subsection{General Advantages and Challenges of Hybrid Grant-Loan Models}

Hybrid grant-loan models benefit from the advantages associated with both loans and grants. The revenue generated from loan interest can support not only the loan program, but the grant program.

\subsection{General Advantages and Challenges to Feed-in-Tariffs}

Well-designed FITs provide a cost-efficient method for encouraging the development of renewable energy, including small hydropower. FIT policies offer a stable investment environment featuring long-term certainty of payment terms (Cory 2009).

However, states must adjust FIT payments for new projects incrementally as technology costs change. Setting the payment level is a complex process requiring robust and sophisticated analysis. Moreover, states must make payment changes transparently and predictably, as “...erratic adjustments may increase project developer uncertainty and reduce investment" (Cory 2009).

\subsection{Comparison of Regulatory Streamlining and Permitting Assistance Programs}

Table 1 highlights the advantages and challenges associated with the state regulatory streamlining and permitting assistance programs discussed in this report, providing an assessment of the state programs: implementation history, design, efficiencies, utilization, administration, ancillary benefits, and overall impact on small hydropower development, among other factors. 
Table 1: Comparison of Regulatory Streamlining and Permitting Assistance Programs

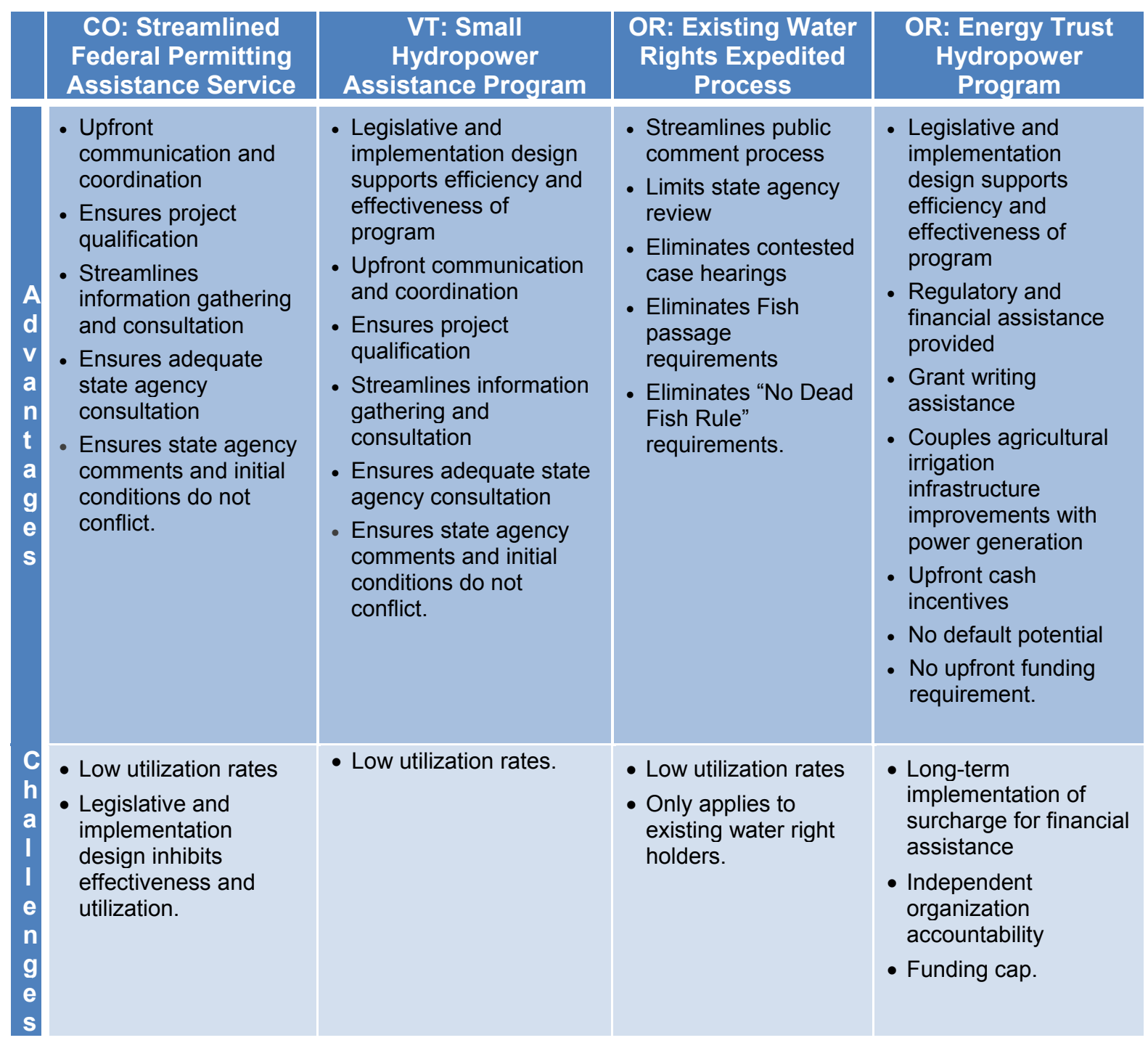




\subsection{Comparison of Financial Incentive Programs}

Table 2 highlights the advantages and challenges associated with the state financial incentive program discussed in this report, providing an assessment of the state programs: implementation history, design, efficiencies, utilization, administration, ancillary benefits, and overall impact on small hydropower development among other factors. 
Table 2: Comparison of Financial Incentives Programs

\begin{tabular}{|c|c|c|c|c|c|c|c|}
\hline & $\begin{array}{l}\text { CO: Water } \\
\text { Power Loan } \\
\text { Program }\end{array}$ & $\begin{array}{l}\text { OR: Small-Scale } \\
\text { Energy Loan } \\
\text { Program }\end{array}$ & $\begin{array}{c}\text { MA: } \\
\text { Commonwealth } \\
\text { Hydropower } \\
\text { Program }\end{array}$ & $\begin{array}{l}\text { CO: RCPP } \\
\text { Irrigation } \\
\text { Hydropower } \\
\text { Program }\end{array}$ & $\begin{array}{l}\text { CO: Small } \\
\text { Hydropower } \\
\text { Loan Program } \\
\text { w/ Match Grant }\end{array}$ & $\begin{array}{l}\text { Rl: Renewable } \\
\text { Energy Growth } \\
\text { Program }\end{array}$ & $\begin{array}{l}\text { VT: Standard } \\
\text { Offer Program }\end{array}$ \\
\hline $\begin{array}{l}\text { A } \\
d \\
\text { v } \\
a \\
\text { n } \\
\text { t } \\
a \\
\text { g } \\
\text { e } \\
\text { s }\end{array}$ & $\begin{array}{l}\text { - Low-interest loan } \\
\text { funding } \\
\text { - Flexible loan } \\
\text { terms } \\
\text { - No funding cap } \\
\text { - No upfront } \\
\text { funding } \\
\text { requirement } \\
\text { - Revolving } \\
\text { revenue stream. }\end{array}$ & $\begin{array}{l}\text { - Low-interest loan } \\
\text { funding } \\
\text { - Flexible loan } \\
\text { terms. }\end{array}$ & $\begin{array}{l}\text { - Upfront cash } \\
\text { incentive } \\
\text { - No repayment } \\
\text { obligations } \\
\text { - No default } \\
\text { potential } \\
\text { - Reliable revenue } \\
\text { stream. }\end{array}$ & $\begin{array}{l}\text { - Upfront cash } \\
\text { incentive } \\
\text { - No repayment } \\
\text { obligations } \\
\text { - No default } \\
\text { potential } \\
\text { - Couples } \\
\text { agricultural } \\
\text { irrigation } \\
\text { infrastructure } \\
\text { improvements } \\
\text { with power } \\
\text { generation. }\end{array}$ & $\begin{array}{l}\text { - Low-interest loan } \\
\text { funding } \\
\text { - Flexible loan } \\
\text { terms } \\
\text { - Flexible loan } \\
\text { terms } \\
\text { - No up-front } \\
\text { funding } \\
\text { requirement } \\
\text { - Upfront cash } \\
\text { incentive } \\
\text { (possible). }\end{array}$ & $\begin{array}{l}\text { - Predicable return } \\
\text { on investment } \\
\text { - Reliable revenue } \\
\text { stream. }\end{array}$ & $\begin{array}{l}\text { - Predicable return } \\
\text { on investment } \\
\text { - Reliable revenue } \\
\text { stream. }\end{array}$ \\
\hline $\begin{array}{l}\text { C } \\
\text { h } \\
\text { a } \\
\text { II } \\
\text { e } \\
\text { n } \\
\text { g } \\
\text { e } \\
\text { s }\end{array}$ & $\begin{array}{l}\text { - Loan funding } \\
\text { above } \$ 10 \text { million } \\
\text { must receive } \\
\text { state legislative } \\
\text { approval } \\
\text { - Funding } \\
\text { restrictions on } \\
\text { private } \\
\text { developers and } \\
\text { on-farm projects } \\
\text { - Loan revenue } \\
\text { fluctuations } \\
\text { based on other } \\
\text { water resource } \\
\text { priorities. }\end{array}$ & $\begin{array}{l}\text { Default potential } \\
\text { created large } \\
\text { deficit to state } \\
\text { - Defaults could } \\
\text { hurt state } \\
\text { bonding. }\end{array}$ & $\begin{array}{l}\text { - Limited grant } \\
\text { funding. }\end{array}$ & $\begin{array}{l}\text { - Limited grant } \\
\text { funding } \\
\text { - Complex } \\
\text { application } \\
\text { process } \\
\text { - Coordination } \\
\text { challenges } \\
\text { between funding } \\
\text { entities } \\
\text { - Delays between } \\
\text { funding } \\
\text { announcements } \\
\text { - Funding through } \\
\text { reimbursement } \\
\text { only } \\
\text { - Availability of } \\
\text { technical service } \\
\text { providers } \\
\text { required to } \\
\text { access funding. }\end{array}$ & $\begin{array}{l}\text { - Loan revenue } \\
\text { influxes based on } \\
\text { other water } \\
\text { resource } \\
\text { priorities } \\
\text { - } \$ 2 \text { million loan } \\
\text { cap } \\
\text { - Loan eligibility } \\
\text { restrictions. }\end{array}$ & $\begin{array}{l}\text { - Setting the right } \\
\text { price is difficult } \\
\text { and complex } \\
\text { - Low utilization } \\
\text { rates. }\end{array}$ & $\begin{array}{l}\text { - Setting the right } \\
\text { price is difficult } \\
\text { and complex } \\
\text { - Low utilization } \\
\text { rates. }\end{array}$ \\
\hline
\end{tabular}




\subsection{Concluding Thoughts}

Financial incentives alone "may not be sufficient to develop additional small hydropower resources" (Summit Blue Consulting, LLC, 2009; Cox 2016). Regulatory streamlining efforts and permitting assistance programs alone may also not be sufficient to develop additional small hydropower resources. However, a combination of streamlining efforts and financial incentives together, that align with state RPSs and other state policies, may provide the path to success for encouraging small hydropower development. Implementation of incentive programs and other policies that are closely coordinated or bundled often improve overall program and policy efficiency (Cox 2016). 


\section{References}

Ackerman, Susan. 2013. "Public Utility Commission of Oregon Testimony." Salem, OR: Public Utility Commission of Oregon.

Alderman, Carolyn. 2017. Telephone Correspondence. VEPP, Inc., Aug. 1, 2017.

Anderson, Sam. 2017. Telephone and E-mail Correspondences. Colorado Department of Agriculture, Aug. 28, 2017.

Applegate Group, Inc. 2013. Recommendations for Developing Agricultural Hydropower in Colorado. Denver, CO: Colorado Department of Agriculture.

Barad, Amy. 2017. Telephone and E-mail Correspondences. Massachusetts Clean Energy Center. Aug. 16, Sept. 15, Sept. 20, 2017.

Barbose, G. 2016. “U.S. Renewables Portfolio Standards: 2016 Annual Status Report.” LBNL-1005057, Berkeley, CA: Lawrence Berkeley National Laboratory. https://emp.lbl.gov/sites/all/files/lbnl1005057.pdf

Black Rock Consulting, Inc. 2010. Hydropower Potential and Energy Savings Evaluation. Portland, OR: Energy Trust of Oregon.

Brown, Kate. 2016. "Letter to Oregon State Legislature Regarding Oregon Department of Energy Oversight Committee." Salem, Oregon: Oregon State Governor's Office, Jun. 24, 2016.

City Club of Portland. 1980. Report on State Bonds for Small Scale Local Energy Project Loan Fund (State Measure No. 3). Paper 339, Portland, OR: City Club of Portland.

Colorado Energy Office. 2016. PRV-Hydropower Assessment. Denver, CO: Colorado Energy Office.

Colo. Leg. Council (Colorado Legislative Council). 2016. "Memorandum to Water Resources Review Committee Regarding 2016 State Funding for Water Projects.” Denver, CO: Colorado Legislative Council.

Colorado Water Conservation Board (CWCB). 2014. "Northern Colorado Water Conservation District, Letter of Approval." Denver, CO: Colorado Water Conservation Board, Nov. 21, 2014.

2016a. "Southeastern Colorado Water Conservancy District, Letter of Approval." Denver, CO: Colorado Water Conservation Board, Jul. 25, 2016. $\overline{\text { Board. }}$

2016b. Water Project Loan Program Guidelines. Denver, CO: Colorado Water Conservation

2017. Water Project Loan Program Website. Denver, CO: Colorado Water Conservation Board.

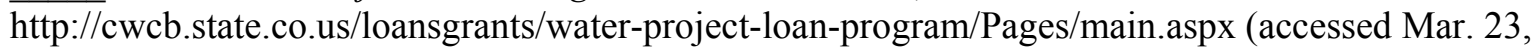
2017).

Colorado Water Resources \& Power Development Authority. 2017. Small Hydropower Loan Program Terms Website. Denver, CO: Colorado Water Resources \& Power Development Autghority.

http://www.cwrpda.com/index.php/programs/small-hydropower-loan-program (accessed Aug. 23, 2017). 
Connolly, Cathleen. 2016. "Memorandum: Oregon Department of Energy, Small Energy Loan Program." Salem, OR: Oregon Department of Adiministrative Services, Apr. 5, 2016.

Cory, K. 2009. State Clean Energy Policies Analysis (SCEPA) Project: An Analysis of Renewable Energy Feed-In-Tariffs in the United States. NREL/TP-6A2-45551. Golden, CO: National Renewable Energy Laboratory.

Cox, S. 2016. Financial Incentives to Enable Clean Energy Deployment Policy Overview and Good Practices. NREL/TP-6A20-65541. Golden, CO: National Renewable Energy Laboratory.

DOE (U.S Department of Energy). 2015. 2014 Hydropower Market Report. DOE/EE-1195, Washington, D.C.: U.S. Department of Energy.

2016. Hydropower Vision Study. Washington, D.C.: U.S. Department of Energy, 2016.

2017a. Renewable Energy Growth Program Website. https://energy.gov/savings/renewableenergy-growth-program. (accessed Mar. 16, 2017).

Doris, Elizabeth. 2009. State of the States 2009: Renewable Energy Development adn the Role of Policy. NREL/TP-6A2-46667, Golden, CO: National Renewable Energy Laboratory.

Douglas, James. 2009. "Letter to Clerk of House of Representatives Regarding H. 446." Montpelier, VT: Vermont House of Representatives. May 27, 2009.

DSIRE. 2017a. Database of State Incentives for Renewables \& Efficiency Webpage. Raleigh, NC: North Carolina State University. www.dsireusa.org. (accessed Jul. 17, 2017).

2017b. Renewable Portfolio Standard-Hydroelectric Map. Raleigh, NC: North Carolina State University. http://programs.dsireusa.org/system/program/maps (accessed Feb. 16, 2017).

Energy Trust of Oregon. 2009. Small Hydroelectric Permitting Handbook - State of Oregon Permitting Process. Portland, OR: Energy Trust of Oregon.

2014. 2015-2019 Strategic Plan. Portaland, OR: Energy Trust of Oregon.

2017. Hydropower Website. https://www.energytrust.org/incentives/renewable-energyhydropower/\#tab-one. (accessed Feb. 17, 2017).

FERC (Federal Energy Regulatory Commission). 2009. "Comment of the National Hydropower Association (NHA): Small Hydropower Devleopment in the United States (Docket No. AD09-9)." Washington, D.C.: Federal Energy Regulatory Commission.

2017. State of the Market Report. Washington, D.C. : Federal Energy Regulatory Commission.

Gouchoe, S., Everette, V., \& Haynes, R. 2002. Case Studies on the Effectiveness of State Financial Incentives for Renewable Energy. NREL/SR-620-32819, Golden, CO: National Renewable Energy Laboratory.

Grainy, Mary. 2017. Telephone Correspondence. Oregon Water Resources Department, Jul. 27, 2017.

Hadjerioua, Boualem, Wei, Y., Kao, S.,. 2012. An Assessment of Energy Potential at Non-Powered Dams in the United States. DE-AC05-000R22725, Washington, D.C.: Oak Ridge National Laboratory. 
Hobbs, John. 2017. Telephone Correspondence. Oregon Department of Energy, Aug. 02, 2017.

Hydro Reform (Hydro Reform Coalition). 2017. State Renewable Portfolio Standards and Hydropower Provisions Table. http://www.hydroreform.org/sites/default/files/2014-07\%20hrc_state_rps_3.pdf (accessed Jul. 21, 2017).

IRENA (International Renewable Energy Agency). 2016. Roadmap for a Energy Future. Abu, Dhabi: International Renewable Energy Agency.

Johnson, K., Hadjerioua, B. 2015. Small Hydropower in the United States. ORNL/TM-2015/326, Oak Ridge, TN: Oak Ridge National Laboratory.

Jorgensen, Jed. 2017. Telephone and E-mail Correspondence. Energy Trust of Oregon, Feb. 2, 2017, Sept. 8, 2017.

Kao, Shih-Chieh, R. McManamay, K. Stewart et al. 2014. New Stream-reach Development: A Comprehensive Assessment of Hydropower Energy Potential in the United States. DE-AC05-000R22725, Washington, D.C.: U.S. Department of Energy.

Kelly-Richards, S., Silber-Coats, N., Crootof, A., Tecklin, D., \& Bauer, C. 2017. "Governing the transition to renewable energy: A review of impacts and policy issues in the small hydropower boom." Energy Policy 101.

Kleinschmidt. 2015. Maine Hydropower Study. Pittsfield, ME: Maine Governor's Energy Office.

Lantz, Eric. 2010. State Clean Energy Policies Analysis: State, Utility, and Municipal Loan Programs. NREL/TP-6A-47376, Golden, CO: National Renewable Energy Laboratory.

Liu, H., Masera, D. and Esser, L. 2013. World Small Hydropower Development Report 2013. United Nations Industrial Development Organization: International Center on Small Hydropower.

Maloney, Peter. 2017. Montana Regulators Vote to Cut PURPA Payment Rates by 40\%. Utility Dive, Aug. 21, 2017.

Margolis, Anne. 2017. Telephone Correspondence. Vermont Public Service Department, Feb. 27, 2017.

Martínez, R., M. Johnson, P. O’Connor. 2017. “U.S. Hydropower Market Report 2017 Update (April)." Oak Ridge National Laboratory, prepared for the U.S. Department of Energy Water Power Technologies Office. https://energy.gov/sites/prod/files/2017/04/f34/US-HydropowerMarket-Report-2017Update_20170403.pdf.

Mass. Tech. Collaborative. 2008. Renewable Energy Results for Massachusetts: A Report on the Renewable Energy Trust Fund 1998-2008. Massachusetts Tech. Collaborative.

MassCEC (Massachusetts Clean Energy Center). 2016. 1.2. Massachusetts Clean Energy Center.

Mauss, Anna. 2017. Telephone Correspondence. Conservation Water Board, Jul. 25, 2017.

Memo (Memorandum of Understanding to Streamline and Simplify the Authorization of Small Scale Hydropower Projects Between FERC and the State of Colorado). Aug. 2010. 
NARUC (National Association of Regulatory Utility Commission). 2011. Analysis of Renewable Energy Policy Options in Vermont. Montpelier, VT: The National Association of Regulatory Utility Commission.

National Grid. 2017. Rhode Island Renewable Energy Growth Program Website.

https://www9.nationalgridus.com/narragansett/business/energyeff/4_dist_gen.asp (accessed Mar. 16, 2017).

NHA (National Hydropower Association). 2009. "Comments to FERC: Small Hydropower Development in the U.S. (Docket No. AD09-9).” Washington, D.C.: National Hydropower Association.

http://www.hydro.org/wp-content/uploads/2011/01/NHA-FERC-Small-Hydro-Comments-Final.pdf.

Navigant Consulting, Inc. 2006. Statewide Small Hydropower Resource Assessment. Sacramento, CA:California Energy Commission.

ODOE (Oregon Department of Energy). 2006. Oregon Renewable Energy Action Plan. Salem, OR: Oregon Department of Energy.

2014. "Administrative Overview." Salem, OR: Oregon Department of Energy, Aug. 2014.

2016. Oregon Energy Loans. Salem, OR, Jun. 2016.

Oregon Department of Administrative Services. 2016. 2017-2019 Governor's Budget State of Oregon.

Salem, OR: Oregon Department of Administrative Service.

Oregon Legislative Fiscal Office. 2017. "State of Oregon Bond Programs." Salem, OR: Oregon

Legislative Fiscal Office, Jan. 2017.

Oregon State Treasury. 2016. "State Treasurer calls for suspension of state Small-Scale Energy Loan Program, citing major defaults and probable bailout." Salem, OR: Oregon State Treasury, Jan. 07, 2016.

Perkins, L. 2013. Cumulative Watershed Impacts for Small-Scale Hydroelectric Projects in Irrigation Delivery Systems: A Case Study. Hood River, OR: Farmers Conservation Alliance, 2013.

Reifer, Samantha. 2017. Correpondence. Colorado Energy Commission, Aug. 2, 2017.

Rhode Island Dep't. of Admin. (Rhode Island Department of Administration). 2015. Energy 2035: Rhode Island State Energy Plan. Providence, RI: Rhode Island Department of Administration.

Rhode Island Off. of Ener. Res Rhode Island Off. of Ener. Res. (Rhode Island Office of Energy Resources). 2014. 2014 Annual Report. Providence, RI: Rhode Island Office of Energy Resources.

Rhode Island Senate Policy Office. 2016. Grow Green Jobs RI. Providence, RI: Rhode Island Senate Policy Office.

Rubin, Mathew. 2017. Telephone Correspondence. SunCommon. Aug. 1, 2017.

Sale, M., Bishop, N., Reiser, S. et al. 2014. Opportunities for Energy Development in Water Conduits: A Report Prepared in Response to Section 7 of the Hydropower Regulatory Efficiency Act of 2013.

ORNL/TM-2014/272. Oak Ridge, TN: Oak Ridge National Laboratoary.

Stokes, B. 2009. "What Exactly is a Feed-In-Tariff?" The National, Apr. 2009. 
Summit Blue Consulting, LLC. 2009. Small Hydropower Technology and Market Assessment in Oregon. Portland, OR: Energy Trust of Oregon.

Taylor, Phil. 2009. Renewable Energy: House Will Get Another Shot at Feed-In-Tariffs. Greenwire, Aug. 3, 2009 .

Thalacker, Marc. 2017. Telephone Correspondence. Three Sisters Irrigation District, Aug. 16, 2017.

EPA (U.S. Environmental Protection Agency). 2017. Renewable Energy Certificates.

https://www.epa.gov/greenpower/renewable-energy-certificates-recs (accessed Jul. 23, 2017).

Vt. Pub. Serv. Board (Vermont Public Service Board). 2013. Order Re: Establishment of Standard-Offer Prices and Programmatic Changes to the Standard-Offer Program. Docket No. 7873-74. Montpelier, VT: Vermont Public Service Board, Mar. 1, 2013.

2017. Order Re: 2017 Technology Allocation and Price Caps for Standard-Offer Program. Docket No. 8817 Montpelier, VT: Vermont Public Service Board, Mar. 3, 2017.

VPSD (Vermont Public Service Department). 2014. Act 165 Report: A Biennial Report to the Vermont General Assembly on Procedres for Faciliting the Development of Small and Micro Hydroelectric Projects. Montpelier, VT: Vermont Public Service Department .

2016. Act 165 Report: A Biennial Report to the Vermont General Assembly on Procedures for Faciitating the Development of Small and Micro Hydroeelectric Projects. Montpelier, VT: Vermont Public Service Department, 2016.

Warren, G. 2013. Hydropower: It's a Small World After All, 91 NEB. L. REV. 925, 936.

2017. Small Hydropower, Big Potential: Considerations For Responsible Global Development, 53 IDAHO L. REV. 149, 173 (2017).

Williams, Wesley. 2017. Telephone Correspondence. Colorado Water Resources \& Power Development Authority, Aug. 21, 2017.

\section{Federal and State Acts and Statutes and Bills}

Bureau of Reclamation Small Conduit Hydropower Development and Rural Jobs Act, PL 113-24, 127 Stat. 498 (Aug. 9, 2013).

Consolidated and Further Continuing Appropriations Act, 2013, PL 113-6,127 Stat. 198 (Mar. 26, 2012).

Hydropower Regulatory Efficiency Act of 2013, PL 113-23, 127 Stat. 493 (Aug. 9, 2013).

Federal Power Act of 1920, PL 66-281, 41 Stat. 1063 (16 U.S.C. §§ 791-823d) (June 10, 1920).

2013 Conn. Pub. Acts 13-303, An act concerning Connecticut's clean energy goals.

1997 Mass. Acts 164, An act relative to restructuring the electric utility industry in the Commonwealth, regulating the provision of electricity and other services, and promoting enhanced consumer protections therein.

2008 Mass. Acts Ch. 307, An act relative to Green Jobs in the Commonwealth. 
2014 R.I. Acts \& Resolves 39, Affordable Clean Energy Security Act.

2009 Vt. Acts \& Resolves 45, An act relating to renewable energy and energy efficiency.

2012 Vt. Acts \& Resolves 170, An act relating to the Vermont Energy Act of 2012.

2012 Vt. Acts \& Resolves 165, An act relating to expediting development of small and micro hydroelectric projects.

2015 Vt. Acts \& Resolves 56, An act relating to establishing a renewable energy standard.

2002 Cal. Stat. 399.12 - 399.12, California Renewable Portfolio Program.

Colo. REV. STAT. $§ § 37-60$ et seq. (1971), Construction of Water and Power Facilities.

Colo. Rev. StaT. § 37-97-104 (1796), Colorado Water Conservation Board.

COLO. REV. STAT. § 40-2-124 (2004), Renewable Energy Standards.

COLO. Rev. STAT. § 39-29 et seq. (2009), Severance Tax.

COLO. REV. STAT. $\S \S 24-38.5$ et seq. (2014), Colorado Energy Office.

MASS. GEN. LAWS 23J § 2 (2008), Massachusetts Clean Energy Technology Center.

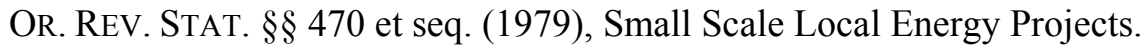

OR. REV. STAT. $\S 543$ et seq. (2013), Hydroelectric Projects.

R.I. GEN. LAWS $\S \S 39-31$ et seq. (2014), Affordable Clean Energy Security Act.

R.I. GEN. LAWS §§39-26 et seq. (2004), Renewable Energy Standard.

30 Vt. Stat. AnN. $\S 8001$ et seq. (2005), Renewable Energy Programs.

\section{Federal and State Regulations}

18 C.F.R $\S \S 4.1$ - 50.11 (1947), Regulations under the Federal Power Act.

18 C.F.R. $\S \S 292.101$ - 292.602 (1980), Regulations under Sections 201 and 210 of the Public Utility Regulatory Policy Act of 1978 with Regard to Small Power Production and Cogeneration.

CAL. Pub. RES. CODE REGS. $\S \S 25740-25751$ (2015), Renewable Energy Resource Program.

26-3000-3008 DEL. AdMIN. CODE $§ 1$ (2013), Rules and Procedures to Implement the Renewable Energy Portfolio Standard.

225 CODE OF MASS. REG. 14, Renewable Portfolio Standard: Class I.

MD. CoDE REG. §§ 7-701 et seq. (2004), Public Utilities.

OR. REV. StAT. §§ 470 et seq. (1979), Small Scale Local Energy Projects. 
OR. ADMIN. R. $\S \S 330-110$ et seq. (2013), Oregon Department of Energy - Small Sale Energy Loan Program Rules.

S.B. $1149,70^{\text {th }}$ Leg., Reg. Sess. (Or. 1999), Electric Deregulation.

S.B. $838,74^{\text {th }}$ Leg., Reg. Sess. (Or. 2007) (enacted) amended by S.B. $1547,78^{\text {th }}$ Leg., Reg. Sess. (Or. 2016) (enacted), Renewable Portfolio Standard.

OR. H.B. 2756, $79^{\text {th }}$ OR. LEG. ASS. [2017]). Transfers duties, functions and powers of the State Department of Energy related to issuance of loans for small scale local energy projects to Oregon Business Development Department. 